\title{
THE
}

\section{Formaldehyde over North America and the North Atlantic during the summer 2004 INTEX campaign: Methods, observed distributions, and measurement-model comparisons}

\author{
Alan Fried \\ James G. Walega \\ Jennifer R. Olson \\ Jim H. Crawford \\ Gao Chen \\ See next page for additional authors \\ Follow this and additional works at: https://digitalcommons.uri.edu/gsofacpubs \\ Terms of Use \\ All rights reserved under copyright.
}

\section{Citation/Publisher Attribution}

Fried, A., et al. (2008), Formaldehyde over North America and the North Atlantic during the summer 2004 INTEX campaign: Methods, observed distributions, and measurement-model comparisons, J. Geophys. Res., 113, D10302, doi: 10.1029/2007JD009185.

Available at: https://doi.org/10.1029/2007JD009185

This Article is brought to you for free and open access by the Graduate School of Oceanography at DigitalCommons@URI. It has been accepted for inclusion in Graduate School of Oceanography Faculty Publications by an authorized administrator of DigitalCommons@URI. For more information, please contact digitalcommons-group@uri.edu. 


\section{Authors}

Alan Fried, James G. Walega, Jennifer R. Olson, Jim H. Crawford, Gao Chen, Petter Weibring, Dirk Richter, Chad Roller, Frank K. Tittel, Brian G. Heikes, Julie A. Snow, Haiwei Shen, Daniel W. O'Sullivan, Michael Porter, Henry Fuelberg, Jeremy Halland, and Dylan B. Millet 


\title{
Formaldehyde over North America and the North Atlantic during the summer 2004 INTEX campaign: Methods, observed distributions, and measurement-model comparisons
}

\begin{abstract}
Alan Fried, ${ }^{1}$ James G. Walega, ${ }^{1}$ Jennifer R. Olson, ${ }^{2}$ Jim H. Crawford, ${ }^{2}$ Gao Chen, ${ }^{2}$ Petter Weibring, ${ }^{1}$ Dirk Richter, ${ }^{1}$ Chad Roller, ${ }^{1,3}$ Frank K. Tittel, ${ }^{4}$ Brian G. Heikes, ${ }^{5}$ Julie A. Snow, ${ }^{6}$ Haiwei Shen, ${ }^{5}$ Daniel W. O'Sullivan, ${ }^{7}$ Michael Porter, ${ }^{8}$ Henry Fuelberg, ${ }^{8}$ Jeremy Halland, ${ }^{8}$ and Dylan B. Millet ${ }^{9,10}$

Received 18 July 2007; revised 26 October 2007; accepted 29 January 2008; published 20 May 2008.

[1] A tunable diode laser absorption spectrometer (TDLAS) was operated on the NASA DC-8 aircraft during the summer INTEX-NA study to acquire ambient formaldehyde $\left(\mathrm{CH}_{2} \mathrm{O}\right)$ measurements over North America and the North Atlantic Ocean from $\sim 0.2 \mathrm{~km}$ to $\sim 12.5 \mathrm{~km}$ altitude spanning 17 science flights. Measurements of $\mathrm{CH}_{2} \mathrm{O}$ in the boundary layer and upper troposphere over the southeastern United States were anomalously low compared to studies in other years, and this was attributed to the record low temperatures over this region during the summer of 2004. Formaldehyde is primarily formed over the southeast from isoprene, and isoprene emissions are strongly temperature-dependent. Despite this effect, the median upper tropospheric (UT) $\mathrm{CH}_{2} \mathrm{O}$ mixing ratio of $159 \mathrm{pptv}$ from the TDLAS over continental North America is about a factor of 4 times higher than the median UT value of 40 pptv observed over remote regions during TRACE-P. These observations together with the higher variability observed in this study all point to the fact that continental $\mathrm{CH}_{2} \mathrm{O}$ levels in the upper troposphere were significantly perturbed during the summer of 2004 relative to more typical background levels in the upper troposphere over more remote regions. The TDLAS measurements discussed in this paper are employed together with box model results in the companion paper by Fried et al. to further examine enhanced $\mathrm{CH}_{2} \mathrm{O}$ distributions in the upper troposphere due to convection. Measurements of $\mathrm{CH}_{2} \mathrm{O}$ on the DC- 8 were also acquired by a coil enzyme fluorometric system and compared with measurements from the TDLAS system.
\end{abstract}

Citation: Fried, A., et al. (2008), Formaldehyde over North America and the North Atlantic during the summer 2004 INTEX campaign: Methods, observed distributions, and measurement-model comparisons, J. Geophys. Res., 113, D10302, doi:10.1029/ 2007JD009185.

\footnotetext{
${ }^{1}$ Earth Observing Laboratory, National Center for Atmospheric Research, Boulder, Colorado, USA.

${ }^{2}$ NASA Langley Research Center, Hampton, Virginia, USA.

${ }^{3}$ Ekips Technology Incorporated, Norman, Oklahoma, USA.

${ }^{4}$ Electrical and Computer Engineering Department, Rice University, Houston, Texas, USA.

${ }^{5}$ Center for Atmospheric Chemistry Studies, Graduate School of Oceanography, University of Rhode Island, Narragansett, Rhode Island, USA.

${ }^{6}$ Department of Geography, Geology, and the Environment, Slippery Rock University, Slippery Rock, Pennsylvania, USA.

${ }^{7}$ Department of Chemistry, United States Naval Academy, Annapolis, Maryland, USA.

${ }^{8}$ Department of Meteorology, Florida State University, Tallahassee, Florida, USA.

${ }^{9}$ Department of Earth and Planetary Sciences, Harvard University, Cambridge, Massachusetts, USA.

${ }^{10}$ Now at Department of Soil, Water, and Climate, University of Minnesota, St. Paul, Minnesota, USA.
}

Copyright 2008 by the American Geophysical Union. 0148-0227/08/2007JD009185

\section{Introduction}

[2] The reactive intermediate formaldehyde $\left(\mathrm{CH}_{2} \mathrm{O}\right)$, which is one of the most abundant gas phase carbonyl compounds in the atmosphere, has been of interest to atmospheric scientists for many years. This gas is formed in the atmosphere from the oxidation of most anthropogenic and biogenic hydrocarbons, primarily initiated by reactions with the hydroxyl $(\mathrm{OH})$ radical and by ozone $\left(\mathrm{O}_{3}\right)$. Formaldehyde is also directly emitted into the atmosphere from biomass burning [Lee et al., 1997], incomplete combustion, industrial emissions, and by emissions from vegetation [Carlier et al., 1986, and references therein]. Typical atmospheric mixing ratios vary from approximately 1 part per billion by volume ( 1 ppbv, 1 part in $10^{9}$ parts of air) in the background continental boundary layer [Harder et al., 1997] to several 10s of ppbv for polluted air over urban regions [Dasgupta et al., 2005] and air influenced by petrochemical refinery emissions (primarily ethene and propene) during summer months [Wert et al., 2003a]. In the remote background atmosphere by contrast, the oxidation of methane 
$\left(\mathrm{CH}_{4}\right)$ becomes the dominant source of $\mathrm{CH}_{2} \mathrm{O}$. In such cases, ambient $\mathrm{CH}_{2} \mathrm{O}$ mixing ratios are typically less than 100 parts per trillion by volume ( 1 pptv, 1 part in $10^{12}$ parts of air), and on the order of 50 pptv or less in the upper troposphere above $8 \mathrm{~km}$ [Fried et al., 2003b].

[3] Methyl hydroperoxide $\left(\mathrm{CH}_{3} \mathrm{OOH}, \mathrm{MHP}\right)$ and methanol $\left(\mathrm{CH}_{3} \mathrm{OH}\right)$, a ubiquitous gas found throughout the atmosphere, can also be important $\mathrm{CH}_{2} \mathrm{O}$ precursors. In the present study the median $\mathrm{CH}_{3} \mathrm{OH}$ mixing ratio ranged between 1 and 4 ppbv (see the 1-min averaged merged data set (publicly available at http://www-air.larc.nasa.gov/ missions/intexna/meas-comparison.htm). Other organic precursors include isoprene, acetone, PAN, various alkanes and alkenes, as well as other aldehydes and ketones, to name a few compound classes. In many cases the production of $\mathrm{CH}_{2} \mathrm{O}$ proceeds through the $\mathrm{CH}_{3} \mathrm{O}_{2}$ radical, which reacts with $\mathrm{NO}$ in producing $\mathrm{CH}_{3} \mathrm{O}$ and ultimately $\mathrm{CH}_{2} \mathrm{O}$ by hydrogen atom abstraction with $\mathrm{O}_{2}$.

[4] Formaldehyde primarily decomposes via three pathways, two involving photolysis and one with $\mathrm{OH}$. As will be discussed in section $3.2, \mathrm{CH}_{2} \mathrm{O}$ can also be lost via dry deposition in the boundary layer. At wavelengths less than $339-n m$ the quantum yield for the radical photolysis channel $\left(2 \mathrm{HO}_{2}+\mathrm{CO}\right)$ is nonzero and this channel becomes dominant at wavelengths less than or equal to 324-nm, while at longer wavelengths than this but shorter than 361-nm the molecular decomposition channel $\left(\mathrm{H}_{2}+\mathrm{CO}\right)$ becomes dominant [Sander et al., 2006].

[5] As $\mathrm{CH}_{2} \mathrm{O}$ is produced as an intermediate from many hydrocarbons, $\mathrm{CH}_{2} \mathrm{O}$ serves as an important test species in evaluating our mechanistic understanding of tropospheric oxidation reactions. Because of the relatively short lifetime of $\mathrm{CH}_{2} \mathrm{O}$ (several hours at midday), $\mathrm{CH}_{2} \mathrm{O}$ is a good tracer for recent photochemical activity. Moreover, Crawford et al. [1999] found that $\mathrm{CH}_{2} \mathrm{O}$ can be twice as sensitive as $\mathrm{HO}_{x}$ $\left(\mathrm{OH}+\mathrm{HO}_{2}\right)$ to changes in precursor species in the upper troposphere, and is thus an ideal candidate for testing the presence of additional $\mathrm{HO}_{\mathrm{x}}$ sources in the upper troposphere. For the purposes of the present study we consider the upper troposphere (UT) at pressure altitudes between 6 and $12 \mathrm{~km}$. Understanding such UT $\mathrm{HO}_{\mathrm{x}}$ sources is important for understanding net ozone production in this region, which in turn impacts the Earth's radiation budget, the ultraviolet flux to the surface, and the production of radical species that are responsible for removal of primary pollutants. The companion paper by A. Fried et al. (Role of convection in redistributing formaldehyde to the upper troposphere over North America and the North Atlantic during the summer 2004 INTEX campaign, submitted to Journal of Geophysical Research, 2008) will focus on this regime.

[6] The Intercontinental Transport Experiment-North America (INTEX-NA) was carried out during the summer of 2004 (1 July to 15 August 2004) over North America and the North Atlantic Ocean on the NASA DC-8 aircraft. This study provided an excellent opportunity to further examine radical chemistry and the role of convection in transporting various $\mathrm{O}_{3}$ and $\mathrm{HO}_{\mathrm{x}}$ precursors to the UT [Singh et al., 2006]. The present paper is the third of four papers regarding $\mathrm{CH}_{2} \mathrm{O}$ measurements over North America and the North Atlantic Ocean during the INTEX-NA campaign. This paper focuses on the instruments and modeling approaches employed and their comparisons as well as the
$\mathrm{CH}_{2} \mathrm{O}$ distributions measured by a tunable diode laser absorption spectrometer (TDLAS). The first paper by Millet et al. [2006] discussed $\mathrm{CH}_{2} \mathrm{O}$ distributions over North America and implications for satellite retrievals. The second paper by Snow et al. [2007] discussed the influence of convection in the UT on $\mathrm{CH}_{2} \mathrm{O}, \mathrm{MHP}$, and hydrogen peroxide as well as an overview of comparisons and contrasts for these three gases with two other airborne campaigns (TOPSE and SONEX). The companion fourth paper by Fried et al. (submitted manuscript, 2008) also discusses the influence of convection on UT $\mathrm{CH}_{2} \mathrm{O}$ mixing ratios but goes into greater detail regarding the statistics of $\mathrm{CH}_{2} \mathrm{O}$ observations and box model results in the UT. All three studies utilize $\mathrm{CH}_{2} \mathrm{O}$ measurements on the NASA DC-8 aircraft acquired by: the TDLAS developed at the National Center for Atmospheric Research (NCAR), and an automated coil enzyme (CENZ) fluorometric system from the University of Rhode Island.

\section{Overview of INTEX-NA Study}

[7] The INTEX-NA study was a multinational, multiagency, and multiplatform campaign [Singh et al., 2006]. The results discussed in this paper are based on measurements from 17 science flights carried out on the NASA DC-8, spanning midlatitudes from the eastern Pacific to the midAtlantic Ocean during the 1 July to 15 August 2004 timeframe at altitudes from $\sim 0.2 \mathrm{~km}$ to $\sim 12.5 \mathrm{~km}$. As shown by the flight tracks in Figure 1, the troposphere over most of the central and eastern United States, southeastern Canada, and the eastern Atlantic Ocean was covered by this study.

[8] As indicated by the meteorological overview of INTEX-NA by Fuelberg et al. [2007], the DC-8 sampled lightning influenced air from $\sim 30 \%$ to $65 \%$ of the time, with many encounters of lightning influenced air occurring within $6 \mathrm{~h}$ of in situ sampling. Fuelberg et al. [2007] also showed that cold frontal passages over the East and Gulf coasts were more frequent than normal, occurring on average every 4.6 d. These fronts were typically preceded by widespread deep convection. This facilitated frequent vertical transport of boundary layer air [Bertram et al., 2007]. However, this anomalously high cold front passage frequency did not allow for stagnant high pressure regions to build up over urban areas with the concomitant build up of pollution. In addition, the large number of cold fronts that passed over the South brought record low temperatures to this region in the summer of 2004, perhaps suppressing the high emissions of isoprene that have been observed in previous years from this region [ $\mathrm{Li}$ et al., 2005]. Thus, although the summer of 2004 was extremely active, deep convection of high boundary layer pollution and biogenic emissions to the UT were perhaps at the lower end of the scale relative to other years (to be discussed in section 4).

\section{Methods}

\subsection{Airborne DC-8 $\mathrm{CH}_{2} \mathrm{O}$ Measurements}

[9] As discussed in section 1, two completely different instruments utilizing different sampling and analytical techniques for the measurement of $\mathrm{CH}_{2} \mathrm{O}$ were employed on the DC-8 during the INTEX-NA study: the TDLAS system from NCAR and the CENZ instrument from the University of Rhode Island. 


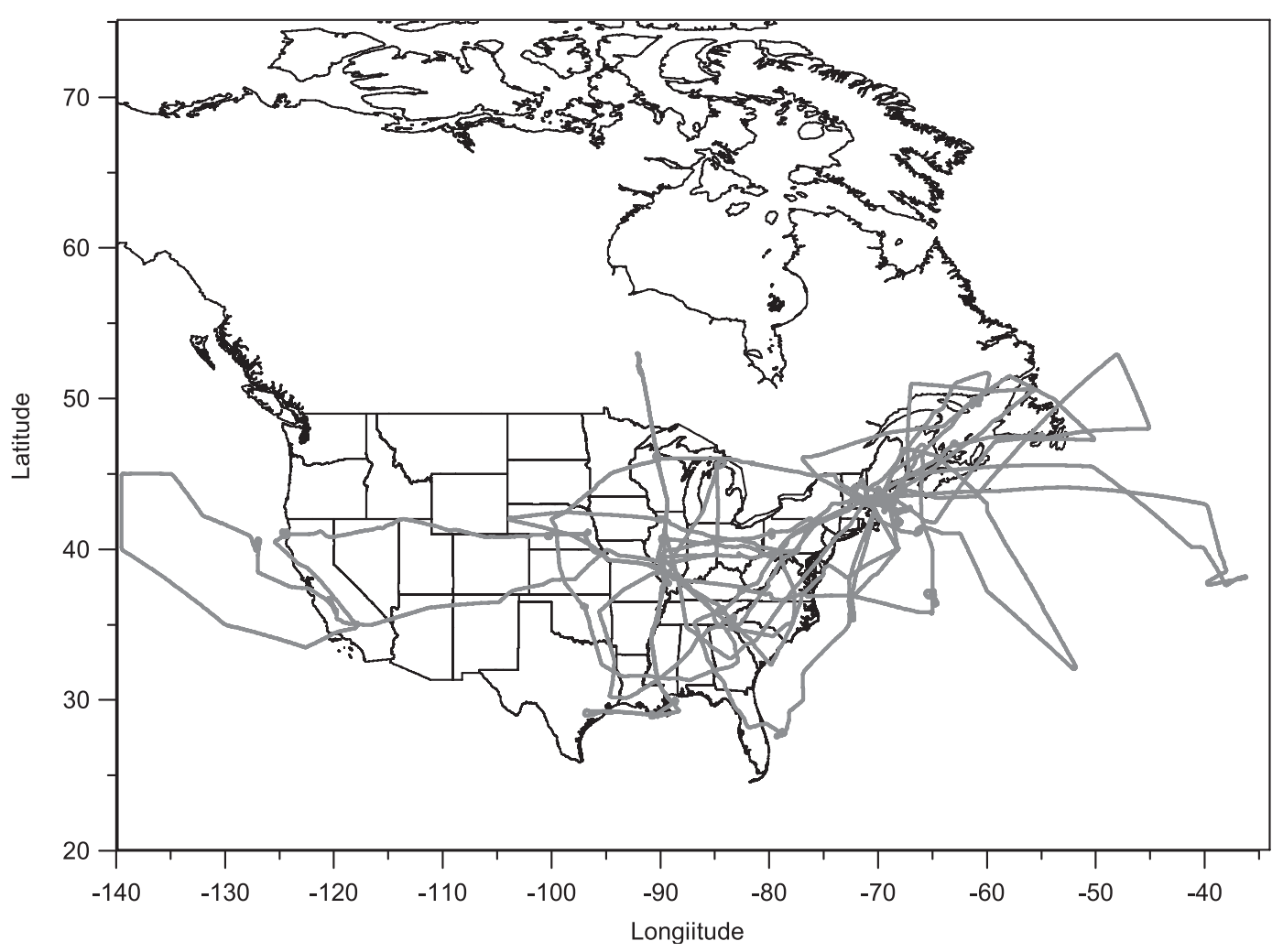

Figure 1. INTEX-NA flight tracks from 1 July to 15 August 2004.

\subsubsection{Airborne TDLAS Instrument}

[10] A detailed description of the TDLAS instrument can be found in the work of Fried et al. [2003b], Wert et al. [2003b], and Roller et al. [2006], and only a brief overview will be presented here. The present instrument is essentially the same as that employed during TRACE-P [Fried et al., 2003b] with one notable exception: the zero air $\mathrm{PdAl}_{2} \mathrm{O}_{3}$ catalyst, which removes $\mathrm{CH}_{2} \mathrm{O}$ but not ambient $\mathrm{H}_{2} \mathrm{O}$, was replaced with a complete Aadco $^{\mathrm{TM}}$ zero air generating system. This system incorporates the same heated catalyst but also two pairs of molecular sieve units, which are alternately back flushed to maintain high scrubbing efficiency for a variety of organics as well as $\mathrm{H}_{2} \mathrm{O}$. Despite this difference, laboratory tests revealed no difference in the TDLAS response when sampling $\mathrm{CH}_{2} \mathrm{O}$ standards in the sub-ppbv range in both dry and humid air $\left(\mathrm{H}_{2} \mathrm{O}\right.$ mixing ratios up to 30,000 parts per million by volume, ppmv). Dry zero Aadco air was employed in these tests for acquisition of background spectra (to be discussed). No difference was observed when the input air to the Aadco unit was humidified up to 30,000 ppmv. Higher mixing ratios were not tested. A number of less dramatic TDLAS modifications have also been implemented to: improve optical stability, improve the robustness of the acquisition code, and incorporate a number of new software diagnostics to help in data quality assessment [Roller et al., 2006].

[11] During INTEX-NA ambient air was continuously drawn through a heated $\left(\sim 35^{\circ} \mathrm{C}\right) 1.3$-cm (OD) PFA Teflon inlet line (perpendicular to the aircraft flow) at $\sim 9$ standard liters per minute $(\mathrm{slm})$, through a pressure controller, and through a multipass Herriott absorption cell maintained at a constant pressure around 50-Torr. The infrared radiation
(3.5- $\left.\mu \mathrm{m}, 2831.6417-\mathrm{cm}^{-1}\right)$ from a liquid nitrogen cooled lead-salt tunable diode laser was directed through this multipass cell where it was selectively absorbed by a moderately strong $\mathrm{CH}_{2} \mathrm{O}$ feature. After achieving a total path length of $100-\mathrm{m}$, the output beam was directed onto a cryogenically cooled InSb sample detector. As discussed by Fried et al. [2003b] the $2831.6 \mathrm{~cm}^{-1}$ line is free from all known spectroscopic interferences with the exception of methanol. Earlier tests indicated a positive interference of $3.8 \%$ on the retrieved $\mathrm{CH}_{2} \mathrm{O}$ mixing ratios for equal methanol mixing ratios. However, subsequent laboratory tests indicated that this interference could be reduced to $0.3 \%$ by employing a wider wavelength range for the fitting algorithm. Although this does not change the spectral overlap between $\mathrm{CH}_{2} \mathrm{O}$ and methanol, it adds more contribution from the neighboring $\mathrm{CH}_{2} \mathrm{O}$ feature $0.057 \mathrm{~cm}^{-1}$ higher in frequency, which reduces the net overall methanol effect. All final data were refit with this wider fitting window and this was further checked by fitting $\mathrm{CH}_{2} \mathrm{O}$ simultaneously with methanol, employing methanol standards input to the instrument after the field study. The median difference in retrieved $\mathrm{CH}_{2} \mathrm{O}$ employing the simultaneous fitting was only 6 pptv ( 15 pptv below $2-\mathrm{km}$ and 4 pptv at higher altitudes).

[12] Ambient $\mathrm{CH}_{2} \mathrm{O}$ measurements were acquired in 1-s increments over time periods ranging from 30 to $60 \mathrm{~s}$, and this was followed by $15 \mathrm{~s}$ of background zero air acquisition, obtained by overflowing the inlet with zero air added a few $\mathrm{cm}$ from the inlet tip. Retrieved $\mathrm{CH}_{2} \mathrm{O}$ mixing ratios were determined for each 1 -s ambient spectrum by fitting to a reference spectrum, obtained by introducing a high concentration calibration gas (12-14 ppbv range) from a 
permeation calibration system into the inlet on top of zero air approximately every hour. More frequent calibrations were sometimes employed and standard additions of calibration samples ( $\sim 5 \mathrm{ppbv})$ were also periodically added to the inlet on both zero and ambient air to check the veracity of the fitting approach and to check for inlet losses. Wert et al. [2003b, and references therein] have documented the validity of employing ppbv level standards in accurately retrieving $\mathrm{CH}_{2} \mathrm{O}$ mixtures at sub-ppbv levels. The timeweighted average of the background spectra surrounding each ambient block and/or calibration block was subtracted point-by-point from each spectrum, and the fitting was performed on the background-subtracted spectra.

[13] Most of the INTEX-NA measurements employed 30-s ambient averages of the 1-s data, which after including flushing periods, background acquisition and computational overhead, took $\sim 1$-min. All such ambient measurements will henceforth be referred to as 1-min averages even though many of the 1-min data blocks were comprised of $30 \mathrm{~s}$ of ambient coverage. The $\mathrm{CH}_{2} \mathrm{O}$ permeation standards were measured before the field mission using direct absorption and resulted in values within $1 \%$ of that determined by gravimetric weight loss. Each daily flight employed from 7 to 18 different calibration measurements, and the retrieved daily average calibration response factor (calibration signal normalized by laser power and calibration mixing ratio) resulted in a standard deviation of $\pm 3.2 \%$ over the entire mission. This ensures that the calibration standards and the system response did not undergo large temporal changes during the mission.

[14] The 1-min detection limit (LOD) at the $2 \sigma$ level was independently determined for each flight based upon the replication precision of the $1-\mathrm{s}$ ambient measurements for mixing ratios less than 500 pptv. Laboratory tests have shown that the instrument measurement precision generally improves by the square root of the averaging time out to averaging periods of 30 to $60 \mathrm{~s}$. Equivalent 1-min precisions were determined from the 1-s precisions by dividing these results by the square root of 30 in all cases (even for $60 \mathrm{~s}$ of averaging, just to be conservative). This procedure was further checked by identifying time periods when the ambient $\mathrm{CH}_{2} \mathrm{O}$ mixing ratios were low and stable for longer than $5 \mathrm{~min}$. In such cases the precision of multiple 1-min determinations yields a direct determination of the 1-min LOD, and these were in good agreement with those based upon the scaled 1-s precisions. As ambient variability can never be ruled out, these LOD estimates are conservative upper limits. Filtering based upon low mixing ratios tends to minimize the influence of ambient variability.

[15] During our first 10 flights (6 July through 28 July), the median 1-min $2 \sigma$ LOD was 82 pptv. Starting with INTEX flight 14 on 31 July 2004, we implemented a number of significant improvements to the mechanical stability of various optical components [Roller et al., 2006] and this improved the median $2 \sigma$ LOD to $66 \mathrm{pptv}$ for the final seven flights. Individual LODs are reported for each 1-min data block in the final merged data set. The systematic uncertainty at the $2 \sigma$ level was estimated at $12.4 \%$ of the ambient $\mathrm{CH}_{2} \mathrm{O}$ mixing ratio, and the total uncertainty for each 1-min average was then derived by quadrature addition of the systematic term with the LOD, $\left[(\mathrm{LOD})^{2}+\left(0.124 *\left[\mathrm{CH}_{2} \mathrm{O}\right]\right)^{2}\right]^{1 / 2}$. In all cases ambient $1-\mathrm{min}$ averages are reported, even those below the LOD as well as negative values, avoiding positive bias when bin averaging. Throughout this paper $\mathrm{CH}_{2} \mathrm{O}$ mixing ratios are given in units of pptv, and as consequence the mixing ratios are specified to the nearest 1 pptv. Of course the instrument LODs must be applied to these values to arrive at the true range within which the mixing ratios are known.

[16] Kormann et al. [2003] discuss their $\mathrm{CH}_{2} \mathrm{O}$ sensitivity to $\mathrm{O}_{3}$ in their MINOS measurements employing a commercial detection system based upon the Hantzsch reaction. They also discuss, and subsequently discount the possibility, that under dry conditions reactions of $\mathrm{O}_{3}$ with terminal alkenes from organic aerosols on contaminated inlet lines could be responsible for artifact $\mathrm{CH}_{2} \mathrm{O}$ formation when sampling stratospheric air [Thomas et al., 2001]. During the TOPSE campaign, our TDLAS $\mathrm{CH}_{2} \mathrm{O}$ measurements employing an inlet similar to the one used in the present study did not yield elevated $\mathrm{CH}_{2} \mathrm{O}$, even though on many occasions these measurements were acquired shortly after sampling hydrocarbon-rich air [Fried et al., 2003a]. This has been further validated in the present study: Our TDLAS $\mathrm{CH}_{2} \mathrm{O}$ measurements in the UT, parsed for stratospheric conditions where $\mathrm{O}_{3}>100 \mathrm{ppbv}$ (100 to $402 \mathrm{ppbv}$ ) and where there were stratospheric encounters within the past $24 \mathrm{~h}$ based upon the meteorological analysis from Fuelberg et al. [2007], likewise did not show any systematic trends with $\mathrm{O}_{3}$; the median TDLAS and box model results in this case were 75 pptv and 88 pptv, respectively. Collectively, these observations strongly indicate that $\mathrm{O}_{3}$ inlet artifacts do not play a role in our UT $\mathrm{CH}_{2} \mathrm{O}$ measurements.

\subsubsection{Airborne CENZ Instrument}

[17] Formaldehyde was also measured on the NASA DC-8 employing an automated coil enzyme (CENZ) fluorometric method, adapted from Lazrus et al. [1988]. Gas phase $\mathrm{CH}_{2} \mathrm{O}$ was removed from the atmosphere by mixing ambient samples with an acidic collection solution in glass stripping coils. The $\mathrm{CH}_{2} \mathrm{O}$ in solution in the presence of the catalyst formaldehyde dehydrogenase $(\mathrm{FDH})$ reacts with nicotinamide adenine dinucleotide (NAD+) to produce $\mathrm{NADH}$. The fluorescence of NADH is proportional to the mixing ratio of $\mathrm{CH}_{2} \mathrm{O}$ in the ambient sample. Prior to the mission, gas phase standards were added at the inlet under different pressures to calibrate the in-flight collection efficiency, which varied with inlet pressure. The collection efficiency dropped from 0.93 at $1000 \mathrm{hPa}$ to 0.68 at $300 \mathrm{hPa}$. The CENZ system used a diffuser type inlet which pressurized the sample, depending upon airspeed and altitude. The inlet consisted of a 1.3-cm (OD) PFA Teflon line $\sim 3 \mathrm{~m}$ in length, which alternatively directed the sample flow $(1.25 \mathrm{slm})$ to one of two aqueous collection coils via a four-way switching valve. Ultrapure zero air was directed into the other coil using the same switching valve and a blank was recorded simultaneously with the ambient signal (signal plus background) in the other channel. The valve was periodically switched to acquire the blank and ambient signals in the opposite coils. Blanks were then interpolated in time for each channel. About once an hour, an excess flow of ultra zero air was introduced approximately $10 \mathrm{~cm}$ from the inlet tip. The signals from the two channels were sampled once each second and ultimately averaged into 1-min data. Liquid standards were analyzed before each flight to calibrate the instrument. The LOD at the $2 \sigma$ level 
was 50 pptv and the total estimated uncertainty was 50 pptv \pm $30 \%$ of the ambient value for $1 \mathrm{~min}$ averaged samples. The technique has been employed on previous aircraft and ground-based experiments [Heikes, 1992; M. Lee et al., 1998; O'Sullivan et al., 2004].

3.1.3. $\mathrm{CH}_{2} \mathrm{O}$ Data Employed in the Present Study: An Overview of the TDLAS-CENZ Comparison

[18] The present study employed 1-min $\mathrm{CH}_{2} \mathrm{O}$ measurements from both instruments, which are tabulated in the 1-min averaged merged data set (publicly available at http:// www-air.larc.nasa.gov/missions/intexna/meas-comparison. $\mathrm{htm})$. Since there are almost twice as many 1-min data points in this merge from the TDLAS system (71\% coverage) compared to the CENZ system (41\% coverage, which includes LOD data), the present and companion paper by Fried et al. (submitted manuscript, 2008) primarily rely on TDLAS measurements. This is particularly important in avoiding reduced coverage when comparing time coincident measurements and model results. However, in certain circumstances we will show both data sets to indicate overall trends in the UT. A detailed comparison of the $\mathrm{CH}_{2} \mathrm{O}$ measurements from the two instruments will be the topic of another paper and only an overview will be given here.

[19] To confirm that there were no fundamental calibration standard discrepancies between the two instruments, the CENZ sampled the gas phase TDLAS permeation standard while on the ground. The comparison yielded agreement to within $5 \%$, as will be discussed later. A weighted bivariate (minimization of residuals in both $\mathrm{X}$ and $\mathrm{Y}$ ) linear regression fit of all the time coincident inflight ( $\mathrm{N}=2615$ points) CENZ ( $y$ axis) data versus the TDLAS data ( $x$ axis) produced the following relationship:

$$
[\mathrm{CENZ}]=(0.70 \pm 0.005)[\mathrm{TDLAS}]+(11 \pm 6) \mathrm{pptv}, \mathrm{r}^{2}=0.89
$$

The data on both axes were weighted by the reciprocal of the detection limits squared. The intercept is small and the results are highly correlated but the CENZ measurements are $70 \%$ of the TDLAS measurements. A standard nonweighted regression (minimization of Y-values only) yields a slope of 0.64 and a 50 pptv intercept. Likewise the median ratio for CENZ/TDLAS yields a value of 0.71 over the entire mission. These results are opposite in direction to the corresponding values determined during the TRACE-P mission, the reasons for which are not understood at this time: a similarly weighted bivariate regression of CENZ versus TDLAS for all time coincident data $(\mathrm{N}=2005)$ produced the following relationship for the TRACE-P mission:

$$
[\mathrm{CENZ}]=(1.55 \pm 0.009)[\mathrm{TDLAS}]+(-37 \pm 4) \mathrm{pptv}, \mathrm{r}^{2}=0.82
$$

For the present INTEX-NA comparisons, we further calculate the normalized fractional difference of the two measurement sets, (TDLAS-CENZ)/TDLAS, to examine if the discrepancy is dependent upon $\mathrm{CH}_{2} \mathrm{O}$ mixing ratio. The average value of this normalized difference was determined for each bin of the TDLAS data (100 pptv bins up to 2 ppbv and 500 pptv above that) and plotted as a function of the binned average TDLAS measurements, as shown in Figure 2.
There is no observed dependence with mixing ratio for TDLAS bins spanning the range between $\sim 300$ pptv and 6500 pptv and only a slight dependence between 200 and 300 pptv. The 3 bins below this low end ( -100 pptv to $200 \mathrm{pptv}$ ) are increasingly affected by the proximity to the LODs from both instruments and the fact that the TDLAS measurements include all values below LOD (including negative values) while the CENZ data are cutoff below 50 pptv. The bin standard deviations start out high and decrease with $\mathrm{CH}_{2} \mathrm{O}$ mixing ratio, a trend reflecting the dominance of the LODs at the low end and the dominance of the systematic terms at higher mixing ratios.

[20] There does, however, appear to be a temporal trend in the relationship between the CENZ and TDLAS measurements over the course of the study. A determination of the daily flight regression slopes starting with INTEX flight 4 on 6 July 2004 and extending to the last flight 20 on 15 August 2004, indicates improved agreement with time: the CENZ/TDLAS slope starts at a value of 0.65 and increases to 0.85 at the end of the mission. It is important to note that the performance for both instruments was coincidentally improved midway through the campaign: starting with INTEX flight 14 on 31 July for the TDLAS instrument and with flight 16 on 6 August for the CENZ instrument. The optics on the TDLAS instrument were stabilized, as discussed in Roller et al. [2006], and the CENZ instrument incorporated a new electrometer with improved noise characteristics. After these modifications the median CENZ/TDLAS ratio changed from a value of 0.64 (flights over the period 6 July through 28 July) to 0.85 (flights over the period 6 August through 15 August), values similar to the slopes at the start and end of the campaign. The median CENZ/TDLAS ratio for flights on 31 July and 2 August (after the TDLAS modifications but before the CENZ modifications) was 0.65 . There were no other changes to either instrument after 6 August. Improvements in performance, i.e., reduced random variations in both instruments, should not affect the level of agreement unless these improvements simultaneously reduced systematic biases in one or both instruments, which to our knowledge did not occur. Nevertheless, the level of agreement between the two instruments starting on August 6 $(\sim 15 \%)$ falls well within the combined systematic uncertainty estimates.

[21] On 10 August 2004 (between INTEX flights 17 and 18) gas phase TDLAS standards (zero air, $4.5 \mathrm{ppbv}$ and 13 ppbv) were injected into the CENZ inlet and the retrieved CENZ measurements were within $5 \%$ of the input TDLAS values, and subsequent ambient air measurements (within $\sim 1 / 2 \mathrm{~h}$ acquisition time of one another) on the tarmac from both instruments resulted in an average agreement to within $\sim 4 \%$. Thus the standards for the two instruments at the time of this comparison were in agreement as were ambient air measurements on the ground. Unanticipated changes in the TDLAS permeation standards over the mission can be ruled out as the cause of the observed temporal change, since as was noted previously, the daily flight-averaged TDLAS response factors were constant to within $\pm 3.2 \%$.

[22] The general level of agreement between the two $\mathrm{CH}_{2} \mathrm{O}$ instruments on the NASA DC-8 during INTEXNA, which were based upon different measurement princi- 


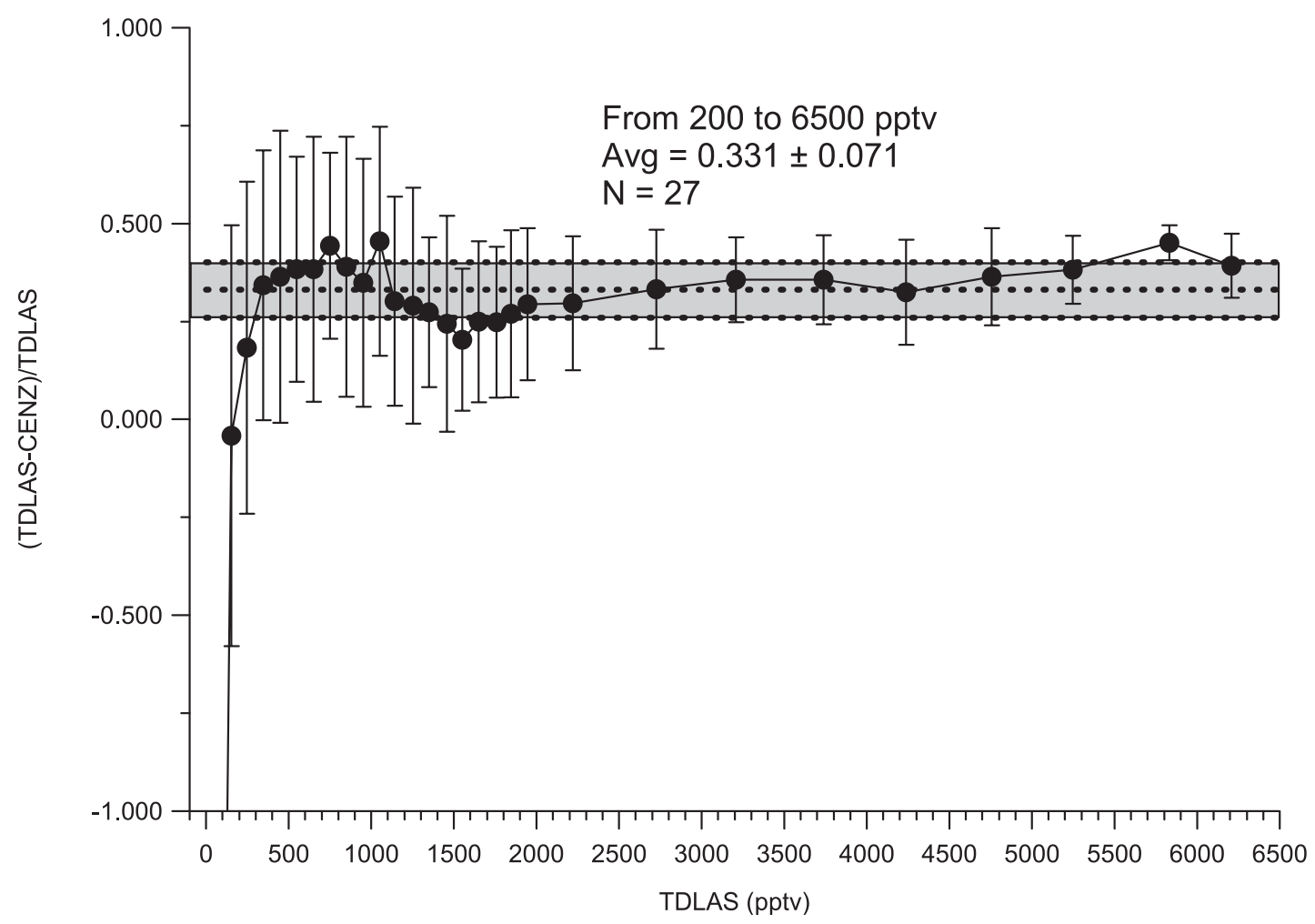

Figure 2. Bin-averaged ( $100 \mathrm{pptv}$ bins for levels below $2 \mathrm{ppb}$ and $500 \mathrm{pptv}$ bins above that) normalized difference (TDLAS-CENZ/TDLAS) for all time coincident 1-min TDLAS and CENZ $\mathrm{CH}_{2} \mathrm{O}$ measurements as a function of the bin-averaged TDLAS measurements. Each data point shows the mean and the $\pm 1 \sigma$ standard deviation of the mean. The dashed lines denote the overall mean and $\pm 1 \sigma$ standard deviation for the bin results over the $200 \mathrm{pptv}$ to $6500 \mathrm{pptv}$ range.

ples and different inlet configurations, strengthens our confidence in the in situ $\mathrm{CH}_{2} \mathrm{O}$ observations in the UT and the conclusions drawn from them in this and the companion manuscript by Fried et al. (submitted manuscript, 2008).

\subsection{Photochemical Box Model}

[23] Model simulations in the present study were carried out employing the NASA Langley time dependent photochemical box model [Crawford et al., 1999; Olson et al., 2001, 2006]. Fried et al. [2003b] further discuss comparisons of box model $\mathrm{CH}_{2} \mathrm{O}$ results with TDLAS measurements during the 2001 TRACE-P campaign, and the reader is referred to these studies for more comprehensive details of the box model. Only a brief overview will be presented here.

[24] For each set of measurements obtained at a given point in time, the model calculates the associated selfconsistent diurnal profile of radical and other computed species as determined from the constraint of long-lived precursors to measured concentrations. Computed radical concentrations at the same point in time as the measurement are then used as the instantaneous model results. This diurnal steady state approach assures that all computed species are in equilibrium with the diurnal process, which is crucial for computed species with lifetimes too long for simple instantaneous steady state assumptions.

[25] The minimum set of input constraints includes observations of $\mathrm{O}_{3}, \mathrm{CO}, \mathrm{NO}_{2}$, nonmethane hydrocarbons (NMHC), temperature, $\mathrm{H}_{2} \mathrm{O}$ (dew/frost point), pressure, and photolysis frequencies. These inputs were obtained from the
12 October 2005 1-min merged data available on the INTEX-NA public data archive (ftp://ftp-air.larc.nasa.gov/ pub-air//INTEXNA). Measurements of NMHCs, which are critical for modeling $\mathrm{CH}_{2} \mathrm{O}$, overlapped TDLAS measurements for $\sim 43 \%$ of the data. To extend this overlap, NMHC measurements were interpolated between consecutive grab samples, obtained at a 4-5 min frequency during horizontal flight legs and every $1-2$ min during vertical ascents or descents. Acetone and methanol were interpolated between adjacent measurements where possible to fill data gaps.

[26] Box model calculations were also constrained by $\mathrm{H}_{2} \mathrm{O}_{2}, \mathrm{MHP}, \mathrm{HNO}_{3}$, and PAN when measurements were available; otherwise, the model calculated these species. As discussed by Fried et al. [2003b] because $\mathrm{CH}_{2} \mathrm{O}$ can be very sensitive to the MHP mixing ratios, measurement-box model comparisons will also be presented where model calculations are restricted to the smaller subset of data limited to points where there are measurements of MHP (see Snow et al. [2007] for MHP measurements). The box model did not include any heterogeneous and/or cloud or halogen chemistry. Dry deposition loss of $\mathrm{CH}_{2} \mathrm{O}$ and other soluble species, such as peroxides, alcohols, nitric acid, pernitric acid, and acetic and formic acids, was invoked below $1 \mathrm{~km}$ at a constant value of $1.0 \times 10^{-5} \mathrm{~s}^{-1}\left(1.2 \mathrm{~cm} \mathrm{~s}^{-1}\right.$ deposition velocity).

[27] Fried et al. [2003b] further discuss the various factors that can impact the model validity, the most important of which is the validity of the steady state assumption, which depends upon $\mathrm{CH}_{2} \mathrm{O}$ lifetime and the presence of 
strong localized sources and sinks of $\mathrm{CH}_{2} \mathrm{O}$ within its lifetime. Over all flight altitudes in the present study the median instantaneous $\mathrm{CH}_{2} \mathrm{O}$ lifetime was $1.8 \mathrm{~h}$ and $1.6 \mathrm{~h}$ for the subset between 6 and $12 \mathrm{~km}$. Thus in most cases in the absence of strong localized perturbations from fresh emissions, the steady state assumption should be valid, particularly in the UT. Likewise, in the UT, surface deposition of $\mathrm{CH}_{2} \mathrm{O}$ and MHP should not be an issue other than possibly in clouds. As in our TRACE-P paper [Fried et al., 2003b], we adopt the sensitivity analysis of Frost et al. [2002] to arrive at an estimate for the random component of the box model uncertainty due to imprecision in the various model input measurements. This results in an approximate $2 \sigma$ random model uncertainty of $24 \%$ of the model mixing ratios. Monte Carlo simulations employing median conditions during INTEX-NA further indicate that $2 \sigma$ systematic uncertainties in the modeled $\mathrm{CH}_{2} \mathrm{O}$ mixing ratios from gas phase reaction rate uncertainties are $51 \%$ in the $0-2-\mathrm{km}$ range and $\sim 60 \%$ elsewhere.

\subsection{GEOS-CHEM Global 3-D Chemical Transport Model}

[28] GEOS-CHEM [Millet et al., 2006, and reference therein], is one of several global 3D chemical transport models run during the INTEX-NA study. Here we use GEOS-CHEM in an attempt to assess if transport and fresh emissions, which are not simulated by the box model, are better represented in 3-D transport models when comparing overall averages. However, as the spatial resolution is rather course $\left(2^{\circ} \times 2.5^{\circ}\right)$, GEOS-CHEM and other global models do not capture localized fine structure. As discussed by Millet et al. [2006], GEOS-CHEM is driven by assimilated meteorology and includes detailed ozone- $\mathrm{NO}_{\mathrm{x}}-\mathrm{VOC}$ chemistry coupled to aerosols.

\section{4. $\mathrm{CH}_{2} \mathrm{O}$ Distributions During INTEX-NA}

[29] Figures $3 \mathrm{a}$ and $3 \mathrm{~b}$ show the $\mathrm{CH}_{2} \mathrm{O}$ distributions acquired by TDLAS in the boundary layer below $2 \mathrm{~km}$ and in the UT above $6 \mathrm{~km}$, respectively, over North America. Figures $4 \mathrm{a}$ and $4 \mathrm{~b}$ show the corresponding data near the coast and over the open Atlantic Ocean, the distinctions for which were determined by the distance to the nearest shoreline (measurements within 150 miles of shoreline were labeled coastal while greater distances denoted open ocean measurements). Tables $1 \mathrm{a}$ and $1 \mathrm{~b}$ tabulate the 1-min TDLAS data in 8 pressure altitude bins over continental North America and over the coastal and open ocean regions combined, respectively.

[30] As can be seen in Figure 3a there is a great deal of variability in continental boundary layer $\mathrm{CH}_{2} \mathrm{O}$ mixing ratios, as expected due to the close proximity to localized sources. In this case mixing ratios varied between 80 pptv to 6783 pptv and produced a median value of 2065 pptv. These values are not very different from those acquired over the southeast boundary layer (denoted in the shaded box of Figure 3a); here 271 TDLAS measurements during mostly clear conditions yield maximum, median, and average values of 6704 pptv, 2592 pptv, and $2899 \pm 1482$, respectively. This is significant since this region is noted for large biogenically derived $\mathrm{CH}_{2} \mathrm{O}$ production from isoprene during summer months [Guenther et al., 2006]. Because of the potential episodic nature of $\mathrm{CH}_{2} \mathrm{O}$ and isoprene emissions and meteorological variability, localized hot spots in one study may not necessarily agree with those from another study. However, overall area averages from studies carried out in similar seasons should in general show similar trends. For example, boundary layer values in the present study over New York State (1-2 ppbv range) are in agreement with ground-based measurements acquired in July of 2002 at Whiteface Mountain, where an average value of $1.4 \mathrm{ppbv}$ was reported by $\mathrm{Li}$ et al. [2004]. However, there are also notable differences. For example, the present boundary layer measurements over the southeast are different from those reported in another aircraft study carried out over this region. Aircraft measurements during the 1995 Southern Oxidants Study (SOS) centered over Nashville, Tennessee by $Y$. $-N$. Lee et al. [1998] produced boundary layer $\mathrm{CH}_{2} \mathrm{O}$ mixing ratios as high as $12 \mathrm{ppbv}$ and a median value of 3.9 ppbv. Likewise the 2001 summertime GOME observations of $\mathrm{CH}_{2} \mathrm{O}$ over the southeast reported a mean boundary layer value of $\sim 5.7 \mathrm{ppbv}$ [Guenther et al., 2006], assuming all of the observed column $\mathrm{CH}_{2} \mathrm{O}$ was confined to a $1.5-\mathrm{km}$ layer. As isoprene was found to be the major source of $\mathrm{CH}_{2} \mathrm{O}$ over this region during the 1995 SOS study, one would expect correspondingly different isoprene levels between the two studies, as was the case: boundary layer midday isoprene attained mixing ratios as high as $4.9 \mathrm{ppbv}$ with a median value of $0.4 \mathrm{ppbv}(\mathrm{N}=155)$ in the present study and this compares to corresponding values as high as $18 \mathrm{ppbv}$ and an overall median value of $0.8 \mathrm{ppbv}(\mathrm{N}=142)$ during the 1995 SOS study [Nunnermacker et al., 1998].

[31] It is important to ascertain whether or not the record low temperatures over the southeast during INTEX-NA are correlated with the reduced $\mathrm{CH}_{2} \mathrm{O}$ and isoprene observations. Over the months of July and August the average surface temperature over this region was approximately 1.5 to $2.5^{\circ} \mathrm{C}$ cooler in 2004 compared to 1995 and about $1^{\circ} \mathrm{C}$ cooler compared to a 10-year average (NOAA Climate Diagnostics Data Center). During flight days the temperature difference was even larger. On the basis of data from the NOAA National Climatic Data Center for flight days during July and August for typical local sampling times between 9 and $18 \mathrm{~h}$ over Nashville, Tennessee, the average surface temperature during INTEX was $4.0^{\circ} \mathrm{C}$ cooler than the SOS study. Using a reduced isoprene emission rate of $\sim 12 \% /{ }^{\circ} \mathrm{C}$ [Guenther et al., 2006], this corresponds to an expected isoprene ratio of 0.52 for INTEX compared to the SOS 1995 study. This value is close to the observed median ratio of 0.5 and suggests that although other factors such as sunlight, soil moisture, and the specific temperature history prior to sampling are important in governing isoprene emissions, the local surface temperatures at the time of sampling appear to play the largest role in the 1995-2004 difference.

[32] Using the above information we next calculate the expected steady state $\mathrm{CH}_{2} \mathrm{O}$ mixing ratio produced from isoprene for the present INTEX-NA study $\left(\left[\mathrm{CH}_{2} \mathrm{O}\right]_{\mathrm{I}}\right)$ relative to that for the $1995 \mathrm{SOS}$ study $\left(\left[\mathrm{CH}_{2} \mathrm{O}\right]_{\mathrm{S}}\right)$ using the following expression:

$$
\frac{\left[\mathrm{CH}_{2} \mathrm{O}\right]_{I}}{\left[\mathrm{CH}_{2} \mathrm{O}\right]_{S}}=\frac{[\text { Isoprene }]_{I}[\mathrm{OH}]_{I}\left(k_{\mathrm{OH}}\right)_{I} \gamma\left(k_{d}\right)_{S}}{[\text { Isoprene }]_{S}[\mathrm{OH}]_{S}\left(k_{\mathrm{OH}}\right)_{S} \gamma\left(k_{d}\right)_{I}}
$$


(a)

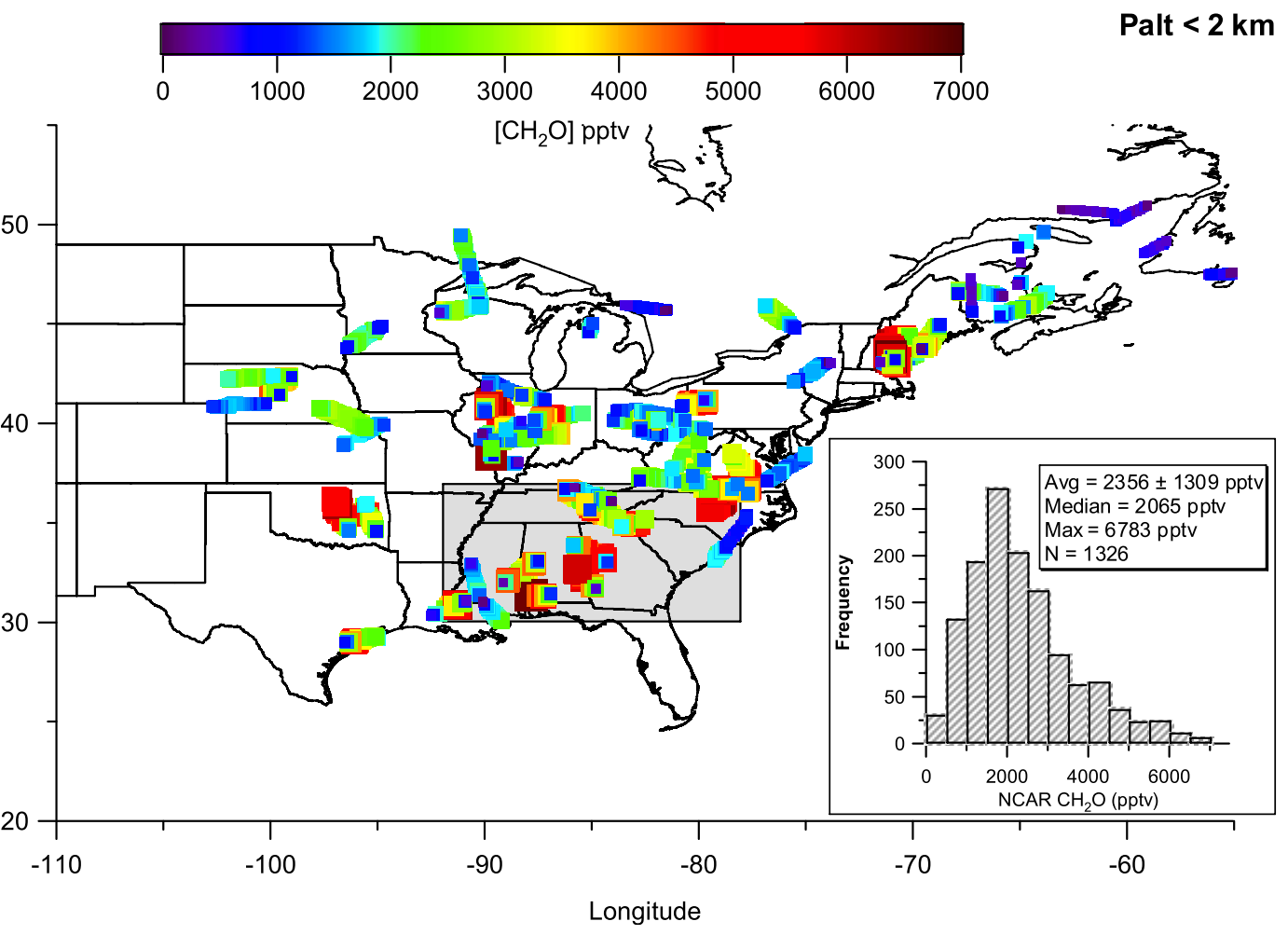

(b)
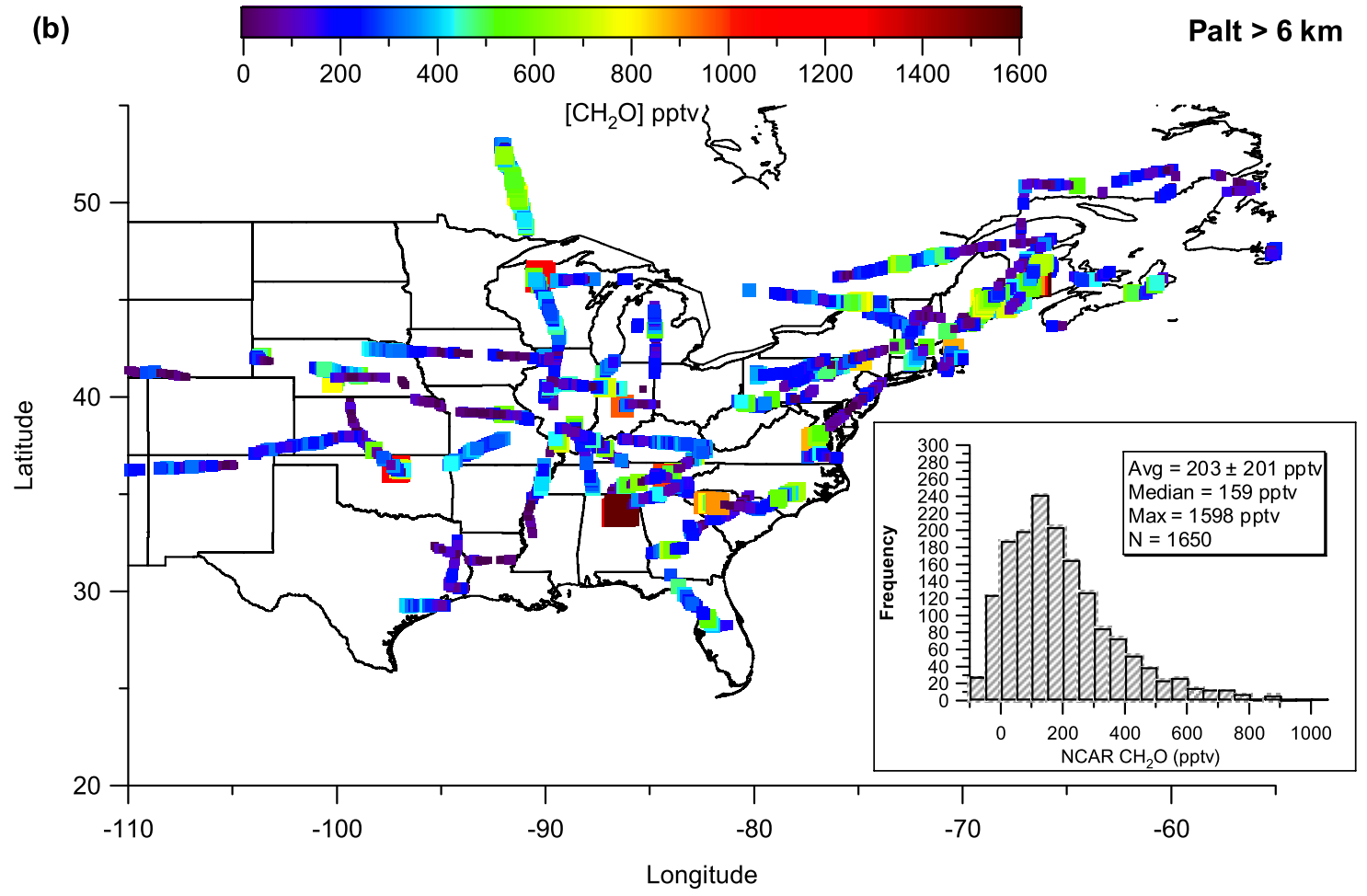

Figure 3. Formaldehyde distributions from the 1-min TDLAS data over North America for (a) pressure altitudes $<2 \mathrm{~km}$ and (b) pressure altitudes $>6 \mathrm{~km}$. The shaded box in Figure 3a denotes the southeast region under consideration. The data are colored and sized by the $\mathrm{CH}_{2} \mathrm{O}$ mixing ratio. The reader should note that the color scale in Figures $3 \mathrm{a}$ and $3 \mathrm{~b}$ are different as are the histogram bin widths (500 pptv in $3 \mathrm{a}$ and $50 \mathrm{pptv}$ in $3 \mathrm{~b}$ ). 
(a)

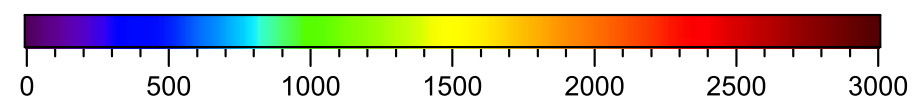

Palt $<2$ km

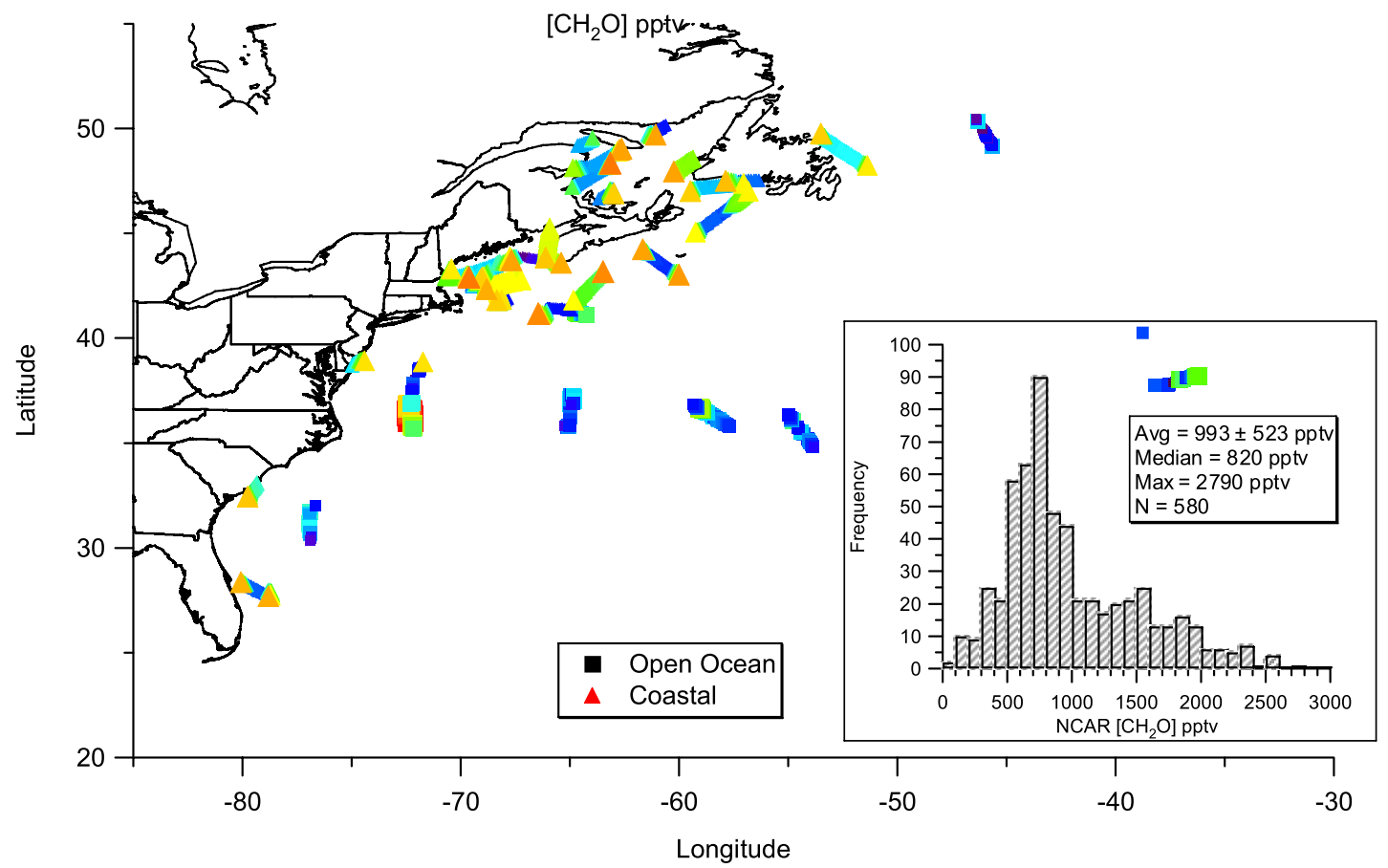

(b)

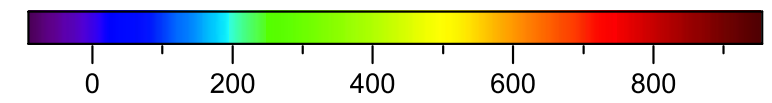

Pat $>6 \mathrm{~km}$

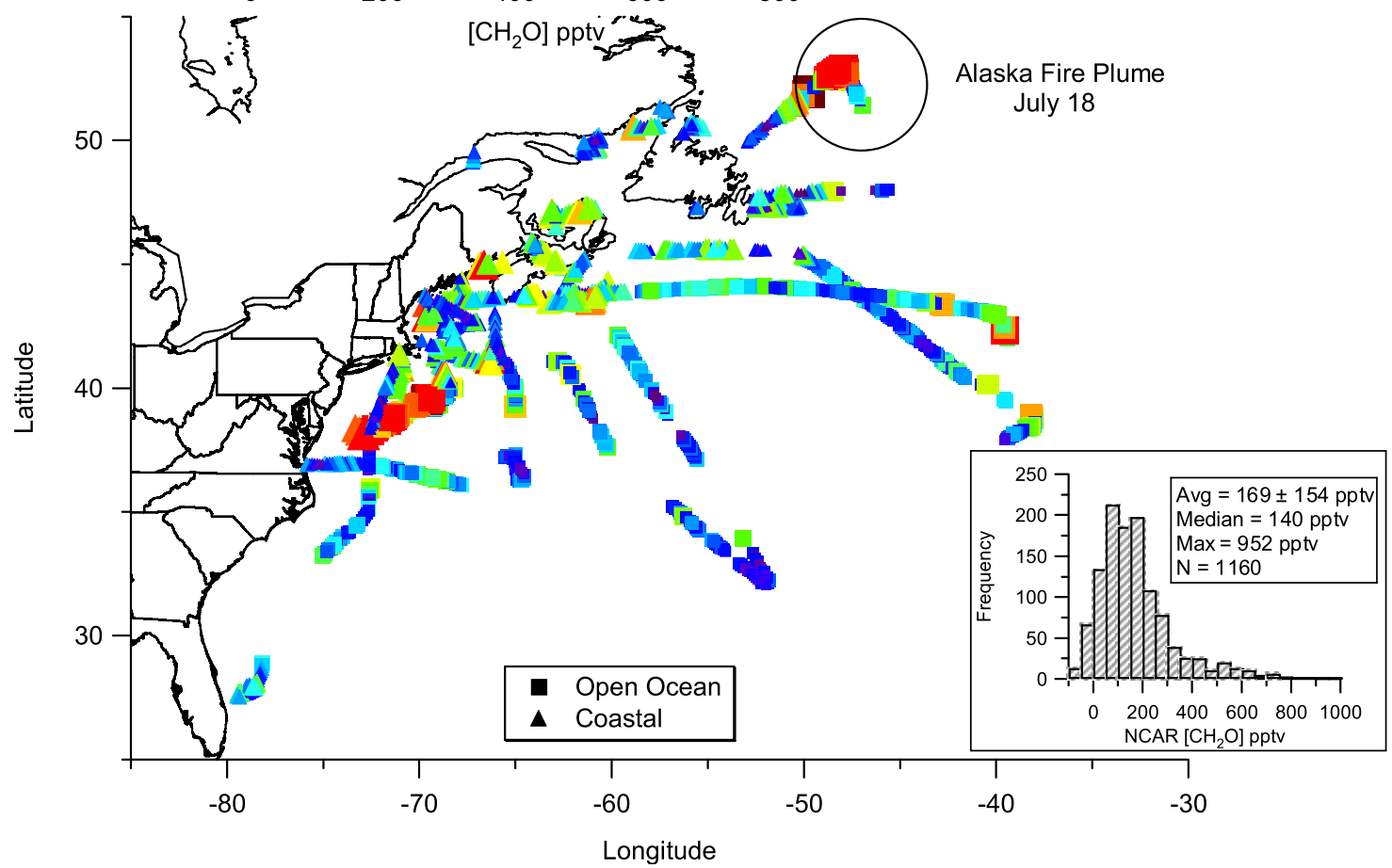

Figure 4. Formaldehyde distributions from the 1-min TDLAS data off the coast of North America (distances from nearest shoreline $<150$ miles) and over the open ocean (distances $>150$ miles) for (a) pressure altitudes $<2 \mathrm{~km}$ and (b) pressure altitudes $>6 \mathrm{~km}$. The data are colored and sized by the $\mathrm{CH}_{2} \mathrm{O}$ mixing ratio. The reader should note that the color scale in Figures $4 \mathrm{a}$ and $4 \mathrm{~b}$ are different and these are different than those in Figure 3. The histograms (100 pptv bins in Figure 4a and 50 pptv bins in Figure 4b) are for coastal and open ocean data combined. 
Table 1a. The 1-min NCAR TDLAS $\mathrm{CH}_{2} \mathrm{O}$ Measurement Statistics (Average With Standard Deviation, Median, and Number of Points) for Different Palt Bins Over Continental North America

\begin{tabular}{lcccc}
\hline Palt Range $(\mathrm{km})$ & Average & Std & Median & $\mathrm{N}$ \\
\hline 0 to 0.5 & 2691 & 1437 & 2217 & 250 \\
0.5 to 1 & 2689 & 1280 & 2263 & 539 \\
1 to 2 & 1865 & 1108 & 1695 & 537 \\
2 to 4 & 662 & 423 & 582 & 638 \\
4 to 6 & 417 & 413 & 330 & 588 \\
6 to 8 & 213 & 213 & 158 & 633 \\
8 to 10 & 223 & 214 & 176 & 574 \\
10 to 12 & 161 & 155 & 132 & 443 \\
\hline
\end{tabular}

${ }^{\mathrm{a}}$ All mixing ratios are in pptv.

This expression was derived from the $\mathrm{CH}_{2} \mathrm{O}$ production rate divided by the destruction rate $\left(\mathrm{k}_{\mathrm{d}}\right)$ for each of the campaigns. As discussed previously, the destruction rates are comprised of three terms: the radical and molecular photolysis channels of $\mathrm{CH}_{2} \mathrm{O}$ and the reaction of $\mathrm{CH}_{2} \mathrm{O}$ with $\mathrm{OH}$. In the SOS study the photolysis frequencies were calculated for noontime clear sky conditions using the TUV model [Madronich, 1987]. In the present study these frequencies were calculated from data acquired by NCAR's scanning actinic flux spectroradiometer mounted onboard the NASA DC-8, a description for which are given by Shetter and Lefer (http://www.espo.nasa.gov/intex-na/contacts complete.html). The terms in brackets represent the isoprene and $\mathrm{OH}$ mixing ratios for the two campaigns, and $\mathrm{k}_{\mathrm{OH}}$ and $\gamma$ are the isoprene-OH reaction rate constants and formaldehyde yields from isoprene for the two campaigns, respectively. The $\mathrm{OH}$ rate constant ratio, $\left(\mathrm{k}_{\mathrm{OH}}\right)_{\mathrm{I}} /\left(\mathrm{k}_{\mathrm{OH}}\right)_{\mathrm{S}}$, is 1.014 for the appropriate temperatures of the two campaigns and the formaldehyde yields are assumed to be constant. The median boundary layer $\mathrm{OH}$ mixing ratio over the southeast in the present study was $4.2 \times 10^{6}$ molecules $\mathrm{cm}^{-3}$ (measured on the DC-8 by Ren et al. [2008]) while that during the SOS study was $\sim 1 \times 10^{7}$ molecules $\mathrm{cm}^{-3}$ (modeled values) around midday [Y.-N. Lee et al., 1998]. Substituting these values together with the $\mathrm{CH}_{2} \mathrm{O}$ destruction rates of $\left(\mathrm{k}_{\mathrm{d}}\right)_{\mathrm{I}}=1.1 \times 10^{-4} \mathrm{~s}^{-1}$ and $\left(\mathrm{k}_{\mathrm{d}}\right)_{\mathrm{S}}=1.7 \times$ $10^{-4} \mathrm{~s}^{-1}$, and the median isoprene mixing ratios of $[\text { Isoprene }]_{\mathrm{I}}=0.4-\mathrm{ppbv}$ and $[\text { Isoprene }]_{\mathrm{S}}=0.8 \mathrm{ppbv}$ into expression (3a) yields:

$$
\frac{\left[\mathrm{CH}_{2} \mathrm{O}\right]_{I}}{\left[\mathrm{CH}_{2} \mathrm{O}\right]_{S}}=0.33
$$

The final step in this analysis is to compare this value of 0.33 to the $\mathrm{CH}_{2} \mathrm{O}$ mixing ratios actually observed during the two campaigns attributable to isoprene. During the 1995 SOS study, Y.-N. Lee et al. [1998] estimated that isoprene was responsible for producing $67 \%$ of the $\mathrm{CH}_{2} \mathrm{O}$ in the boundary layer over the southeast while the box model results during INTEX-NA yield a corresponding median isoprene contribution of $39 \%$. This yields the following for the actual $\mathrm{CH}_{2} \mathrm{O}$ ratio for the two campaigns produced by isoprene:

$$
\frac{\left[\mathrm{CH}_{2} \mathrm{O}\right]_{I}}{\left[\mathrm{CH}_{2} \mathrm{O}\right]_{S}}=\frac{2592 p p t v(0.39)}{3900 p \operatorname{ptv}(0.67)}=0.39
$$

The result of equation (3c) is within $18 \%$ of that estimated from (3b). Although this analysis is approximate due to many assumptions, including the cancellation of potential errors in modeling the isoprene contributions to the $\mathrm{CH}_{2} \mathrm{O}$ source in both studies, it suggests that the cooler temperatures over the southeast could indeed be largely responsible for the reduced $\mathrm{CH}_{2} \mathrm{O}$ produced from isoprene in 2004 compared to 1995 , and most likely, other years as well.

[33] Additional modeling studies and satellite observations over the southeastern United States during summer [ $\mathrm{Li}$ et al., 2005; Müller and Brasseur, 1999; Palmer et al., 2003], indicate that biogenically generated $\mathrm{CH}_{2} \mathrm{O}$ coupled with frequent deep convection and chemical aging caused by circulation around a semi-permanent upper level anticyclone, are responsible for enhanced ozone in the UT over this region. This air is then transported to the northeast and eventually out over the Atlantic. The present study does not show this. In the UT around $9 \mathrm{~km}$, the median and third quartile TDLAS $\mathrm{CH}_{2} \mathrm{O}$ mixing ratios were 108 pptv and $251 \mathrm{pptv}$, respectively, over the southeast. This is in contrast to GEOS-CHEM simulations of 500 to $760 \mathrm{pptv}$ at $\sim 9 \mathrm{~km}$ by $L i$ et al. [2005] for the year 2000 over this region. Even though we observed a maximum $\mathrm{CH}_{2} \mathrm{O}$ value of $1549 \mathrm{pptv}$ over Alabama, $90 \%$ of the TDLAS observations were less than 487 pptv.

[34] Collectively the above observations all suggest that the upper tropospheric $\mathrm{CH}_{2} \mathrm{O}$ levels in the present study originating over the southeast and transported northeasterly are perhaps anomalously low compared to other years. Nevertheless, the median upper tropospheric TDLAS $\mathrm{CH}_{2} \mathrm{O}$ mixing ratio of 159 pptv (Figure $3 \mathrm{~b}$ ) over continental North America (maximum $=1598 \mathrm{pptv}$ ) is about a factor of 4 times higher than the median UT value of 40 pptv $(\mathrm{N}=$ 874 , maximum $=320 \mathrm{pptv}$ ) observed over remote regions of the central and eastern Pacific Ocean during TRACE-P [Fried et al., 2003b]. Moreover, the variability (10 to 90th percentile measurement difference) of the present measurements (439 pptv) is about a factor of 3 higher than during TRACE-P (153 pptv). These observations all indicate that continental UT $\mathrm{CH}_{2} \mathrm{O}$ levels are perturbed relative to background values. Additional evidence for this, which is presented in the companion paper by Fried et al. (submitted manuscript, 2008), arises from enhanced $\mathrm{CH}_{2} \mathrm{O}$ precursors transported to the UT by convection and enhanced NO from lightning and from the stratosphere.

[35] The median boundary layer $\mathrm{CH}_{2} \mathrm{O}$ mixing ratio of 2065 pptv over continental North America is more than twice the value of $820 \mathrm{pptv}$ obtained for the combined

Table 1b. The 1-min NCAR TDLAS $\mathrm{CH}_{2} \mathrm{O}$ Measurement Statistics for Different Palt Bins Over the Atlantic Ocean, Which Includes Open Ocean and Coastal Regions Combined ${ }^{\mathrm{a}}$

\begin{tabular}{ccccc}
\hline Palt Range $(\mathrm{km})$ & Average & Std & Median & N \\
\hline 0 to 0.5 & 1073 & 564 & 892 & 325 \\
0.5 to 1 & 1052 & 529 & 838 & 84 \\
1 to 2 & 812 & 378 & 731 & 172 \\
2 to 4 & 445 & 241 & 413 & 261 \\
4 to 6 & 290 & 316 & 226 & 200 \\
6 to 8 & 221 & 174 & 180 & 337 \\
8 to 10 & 142 & 115 & 129 & 591 \\
10 to 12 & 162 & 187 & 104 & 232 \\
\hline
\end{tabular}

${ }^{\mathrm{a}}$ All mixing ratios are in pptv. 
coastal and open ocean regimes shown in the inset in Figure $4 \mathrm{a}$. This is expected due to the closer proximity of the former to localized sources of $\mathrm{CH}_{2} \mathrm{O}$ and its precursors. At mixing ratios up to $600 \mathrm{pptv}$, the histogram in Figure $4 \mathrm{a}$ is primarily dictated by open ocean measurements, while mixing ratios higher than 700 pptv are primarily dictated by coastal measurements. Between 600 and 700 pptv both contributions are nearly equivalent. However, by contrast, the UT median values for continental North America (159 pptv) and the lumped open ocean and coastal values (140 pptv) are similar, indicating that transport of $\mathrm{CH}_{2} \mathrm{O}$ and its precursors as well as in situ production in the UT over more remote regions of the Atlantic Ocean is efficient. As seen in Figure $4 \mathrm{~b}$, many of the UT elevated $\mathrm{CH}_{2} \mathrm{O}$ events occur near the North American coastline, however, elevated $\mathrm{CH}_{2} \mathrm{O}$ observations as high as 400 pptv were also recorded long distances from the coastline. Figure $4 \mathrm{~b}$ also shows the intercept of an Alaskan fire plume at an altitude around $7 \mathrm{~km}$. Here $\mathrm{CH}_{2} \mathrm{O}$ levels were as high as 952 pptv from Alaskan fires that had originated several days prior.

\section{Measurement Box Model Comparisons}

[36] Measurement box model comparisons for $\mathrm{CH}_{2} \mathrm{O}$ have had a rather long history with varying results, and the reader is referred to Fried et al. [2003a, 2003b] and Kormann et al. [2003] and references therein for comprehensive details. As discussed in these references, box models have at times underestimated, overestimated, and accurately simulated $\mathrm{CH}_{2} \mathrm{O}$ observations, depending upon the measurement regime. In the lower troposphere, box models generally tend to underestimate $\mathrm{CH}_{2} \mathrm{O}$ observations in the presence of fresh emissions [Fried et al., 2003b]. Because the lifetime of $\mathrm{CH}_{2} \mathrm{O}$ is short (usually on the order of a few hours), cases where direct emissions of $\mathrm{CH}_{2} \mathrm{O}$ become important are not generally encountered in remote or rural areas. However, the validity of model diurnal steady state may break down in the boundary layer in urban environments due to fresh emissions of $\mathrm{CH}_{2} \mathrm{O}$ and/or its short-lived precursors such as ethene and isoprene. Because diurnal steady state constrains nonmethane hydrocarbons to measured values, this approach may underestimate the recent history of photochemical production of $\mathrm{CH}_{2} \mathrm{O}$ from these very short-lived hydrocarbons as they rapidly decay. The model is also limited by the availability of measurements of important $\mathrm{CH}_{2} \mathrm{O}$ precursors such as MHP and methanol, and, particularly in the case of fresh pollution, unmeasured hydrocarbon species. In addition, measurements of $\mathrm{CH}_{2} \mathrm{O}$, its precursors, and $\mathrm{NO}_{\mathrm{x}}$ were acquired over different integration times (typically $30 \mathrm{~s}$ out of each minute for $\mathrm{CH}_{2} \mathrm{O}$ and $\mathrm{MHP}$, methanol $2 \mathrm{~min}$, canister hydrocarbon acquisitions $\sim 1$ to $2 \mathrm{~min}$ ) and starting times within each 1-min comparison period, and therefore in fresh plumes the precise data overlap becomes more important than in more diffuse aged plumes. In such cases there is a greater chance of $\mathrm{CH}_{2} \mathrm{O}$ measurement-model disparity simply from imperfect data overlap. In fact, the four largest measurement/model ratios for $\mathrm{CH}_{2} \mathrm{O}$ all show poor data overlap; in the case of the largest ratio (measurement/model $=20.8$ ) there is only $5 \%$ and $20 \%$ coverage, respectively, for $\mathrm{CH}_{2} \mathrm{O}$ and $\mathrm{NO}_{\mathrm{x}}$. Throughout the rest of this paper these various effects are collectively referred to as input pertur- bations to the box model. Fried et al. [2003b] have also shown box model results that overestimate observations when sampling in clouds and in the lower marine troposphere in the absence of fresh emissions. Uptake of $\mathrm{CH}_{2} \mathrm{O}$ is not modeled accurately in these cases.

[37] However, in the absence of these effects, Fried et al. [2003b] have also shown that despite point-to-point scatter, on average one can obtain good agreement between $\mathrm{CH}_{2} \mathrm{O}$ measurements and box model calculations throughout the troposphere from the surface to $12 \mathrm{~km}$. This implies that away from local sources and sinks we generally have a good understanding of $\mathrm{CH}_{2} \mathrm{O}$ chemistry in the background atmosphere. Like TRACE-P, very similar comparison results were obtained on average during INTEX-NA throughout the troposphere; a bivariate fit of all the 1-min TDLAS data ( $y$ axis) versus the box model $(\mathrm{N}=3936)$ results in the following:

$$
\begin{aligned}
{\left[\mathrm{CH}_{2} \mathrm{O}\right]_{\text {TDLAS }}=} & (1.20 \pm 0.011)\left[\mathrm{CH}_{2} \mathrm{O}\right]_{\text {Box Model }} \\
& +(119 \pm 10) \mathrm{pptv}, \mathrm{r}^{2}=0.76
\end{aligned}
$$

A corresponding fit of the measurements averaged in 50 pptv bins for model values out to 350 pptv $(\mathrm{N}=6)$ results in the following:

$$
\begin{aligned}
{\left[\mathrm{CH}_{2} \mathrm{O}\right]_{\text {TDLAS }}=} & (1.04 \pm 0.08)\left[\mathrm{CH}_{2} \mathrm{O}\right]_{\text {Box Model }} \\
& +(32 \pm 10) p p t v, \mathrm{r}^{2}=0.97
\end{aligned}
$$

Both results are similar to TRACE-P results by Fried et al. [2003b] regressed in the same way. The TRACE-P slope of all data $<1000$ pptv was 1.38 (intercept $=-39$ pptv) and the slope of the binned average out to mixing ratios of $455 \mathrm{pptv}$ was 0.98 (intercept $=-9$ pptv). In both cases the bin averages deviated upward from the linear fit at mixing ratios well above the 400 pptv range due to model input perturbations in the presence of fresh emissions.

[38] Figure 5 presents another way of comparing TDLAS and box model results. Here the pressure altitude median values for time coincident measurements and model results are plotted in 8 altitude bins for continental, coastal, and open Atlantic Ocean data. These same altitude bins will be employed throughout the rest of this paper. We also show in this plot results from the GEOS-CHEM global 3-D chemical transport model. As can be seen, the median $\mathrm{CH}_{2} \mathrm{O}$ TDLAS measurements and GEOS-CHEM results are in reasonable agreement for all altitudes over continental North America and coastal data but diverge somewhat below $3 \mathrm{~km}$ over the open Atlantic Ocean. In all three domains the box model significantly underestimates the observations at low altitude (below $3 \mathrm{~km}$ for the continental and coastal data and below $1 \mathrm{~km}$ for the open ocean data). Parsing the continental boundary layer data $(0-2 \mathrm{~km})$ for cleaner air masses where $\mathrm{CO}$, ethene, and isoprene measurements were available and below their respective 25-percentile boundary layer values, produces median box model and TDLAS values of 542 pptv and 708 pptv, respectively. Although based on very limited data $(\mathrm{N}=6)$, the model underestimate (difference in median TDLAS and model values $=166 \mathrm{pptv}$ ) for this case is about a factor of 3 less than all continental boundary layer comparisons. 


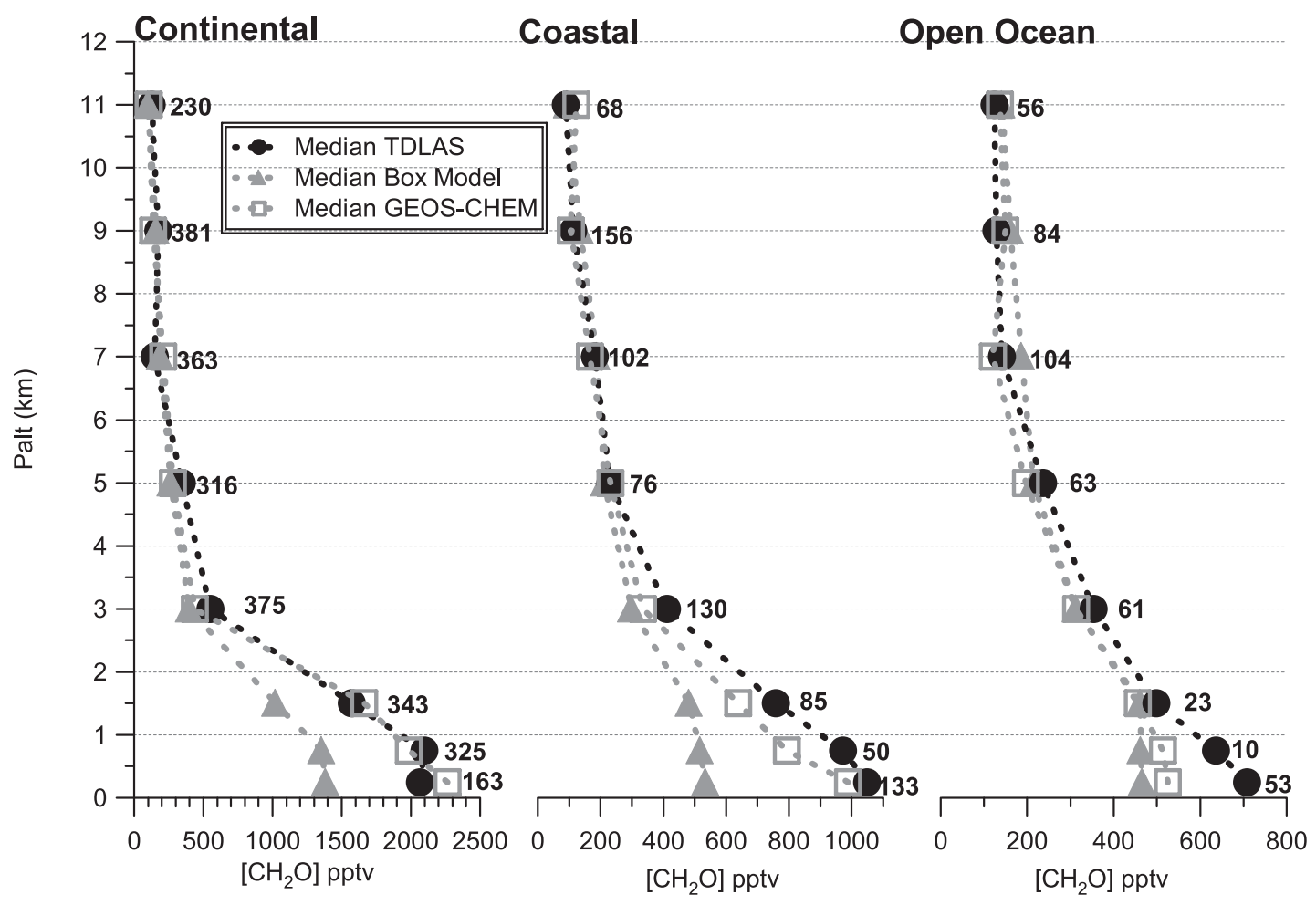

Figure 5. Time coincident 1-min comparisons of $\mathrm{CH}_{2} \mathrm{O}$ altitude binned medians for the TDLAS, box model and GEOS-CHEM model results for continental, coastal, and open Atlantic Ocean data during INTEX-NA. Eight altitude bins ( 0 to $0.5 \mathrm{~km}, 0.5$ to $1 \mathrm{~km}, 1$ to $2 \mathrm{~km}, 2$ to $4 \mathrm{~km}, 4$ to $6 \mathrm{~km}, 6$ to $8 \mathrm{~km}, 8$ to $10 \mathrm{~km}$, and 10 to $12 \mathrm{~km}$ ) are shown. The number of data points in each bin is indicated by the number next to each point. The GEOS-CHEM model incorporates significantly higher input precursor values than measured on the DC-8 and used in the box model and this is responsible for the apparent discrepancy between the two models below $3 \mathrm{~km}$ for the continental and coastal data.

This is suggestive that pressure-dependent errors are not significant.

[39] The apparent improved agreement between the GEOS-CHEM 3-D model and continental-coastal $\mathrm{CH}_{2} \mathrm{O}$ observations below $3 \mathrm{~km}$ relative to comparisons with the box model is fortuitous, however, and can be explained by the fact that the GEOS-CHEM model employs $\mathrm{CH}_{2} \mathrm{O}$ precursor values significantly higher than actually measured on the DC-8 and used in the box model below $3 \mathrm{~km}$; employing the same input precursor values in both models results in a model-to-model agreement to within $20 \%$ for all altitudes. Although discrepancies are still present for low altitude open ocean measurement-box model comparisons, they are significantly less than coastal comparisons; in the 0 to $0.5 \mathrm{~km}$ bin the median point-by-point TDLAS/Box Model ratio is 1.56 for open ocean comparisons and 2.05 for coastal comparisons. In the $1-2-\mathrm{km}$ bin, the former drops to a ratio of 1.08 and the latter to 1.54 .

[40] The TDLAS-box model comparisons in Figure 5 are similar to the behavior demonstrated during TRACE-P [Fried et al., 2003b], only the magnitude of the discrepancies are larger here, particularly below $2 \mathrm{~km}$. In the four altitude bins above $4 \mathrm{~km}$, the medians for the TDLAS and both model results are in reasonable agreement for all locations of the present study. This is similar to the TRACE-P TDLAS-box model comparisons, even close to and over Asian continental regions [Fried et al., 2003b].
This is in spite of differences in the $\mathrm{CH}_{2} \mathrm{O}$ production and destruction terms between the two studies due to differences in geographic regimes and sampling seasons. TRACE-P was carried out in the spring, primarily over remote regions of the Pacific Ocean while INTEX-NA was carried out in the summer primarily near urban source regions. The $\mathrm{CH}_{2} \mathrm{O}$ sources and sinks in the latter were larger than the former. For example, above $4 \mathrm{~km}$ the median $\mathrm{CH}_{2} \mathrm{O}$ lifetime (reciprocal of the destruction rate) was $\sim 40 \%$ longer during TRACE-P than INTEX-NA $(2.2 \mathrm{~h}$ compared to $1.6 \mathrm{~h})$ due to enhanced photolysis frequencies and $\mathrm{OH}$ mixing ratios during the summer months.

[41] Figure 6 examines the relationship between TDLAS measurements and box model results further. Here the ratio of time coincident TDLAS measurements to box model results is plotted as a function of pressure altitude for all geographic locations combined. We show in this plot ratios for all data as well as altitude binned averages, standard deviations, and medians. Only 5 points out of a total of 3981 comparisons have ratios greater than 10 and the plot is restricted to this limit to maintain resolution. The bounds for the combined random measurement-model uncertainty for the binned ratios, shown by the shaded area and bounded by the dark vertical lines, were calculated from the average ratio uncertainty in each altitude bin. The ratio uncertainties $(2 \sigma$-level) were calculated from the quadrature addition of the combined random measurement (measurement LOD) 


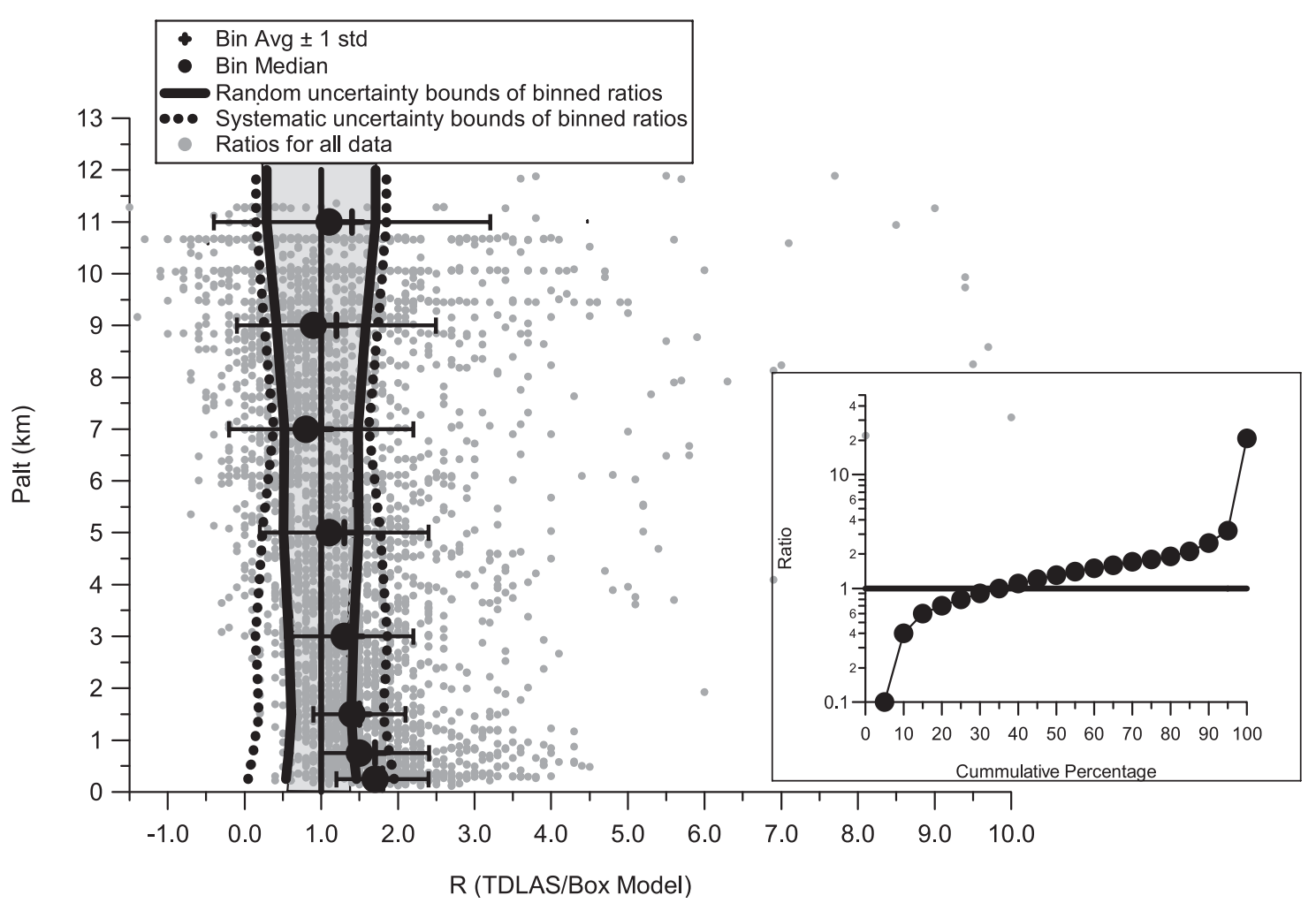

Figure 6. TDLAS/Box Model ratios as a function of pressure altitude for comparison points as well as pressure altitude binned averages and medians. The dark solid vertical lines, which bound the shaded gray area, represent the bounds for the average total random uncertainty in each altitude bin and the dotted black lines represent the corresponding systematic uncertainty bounds. The inset shows the cumulative percentage on a semi-log plot for the TDLAS/Box Model ratios.

and model uncertainties for each comparison point. The bounds for the systematic uncertainties for these ratios (dotted vertical lines) were likewise calculated from the average ratio uncertainties, estimated from the quadrature addition of the systematic terms $(51 \%$ for the model and $12.4 \%$ for the TDLAS measurements in the $0-2-\mathrm{km}$ range and $60 \%$ and $12.4 \%$ for these two elsewhere). Truly systematic uncertainties should only affect the results in one direction; the systematic bounds in Figure 6 are meant to show the number of significant outlier points well beyond the bounds of both limits. As shown, the systematic uncertainties are the largest contributor to the $\mathrm{CH}_{2} \mathrm{O}$ measurement/model ratio uncertainties at low altitudes (typically below $6-\mathrm{km}$ ), while the random and systematic components become equally important at higher altitudes.

[42] Since individual comparison points may have significantly different ratio uncertainties than the bin averages, the error bounds in Figure 6 are meant only as guides to graphically show the number of outliers and their magnitudes. On a point-by-point basis, $47 \%$ of the ratios fall within the combined measurement and model random uncertainties for all the time coincident data $(38 \%$ positive outliers and $15 \%$ negative outliers) and $74 \%$ within the combined systematic limits. In the $6-12-\mathrm{km}$ UT range, $56 \%$ of the ratios fall within the combined random limits $(20 \%$ positive outliers and $24 \%$ negative outliers) and $62 \%$ within the combined systematic limits. The inset, which plots the ratio as a function of the cumulative percentage of the data, indicates that $90 \%$ of the data yield a measurement $/$ model ratio in the range between 0.1 and 3.2. As can be seen in Figure 6, there is a systematic trend in both the median and average ratios with altitude; the ratios start out high at low altitudes and at $5-\mathrm{km}$ and above approach a ratio of 1 . This is consistent with all of our previous measurement-model comparisons, which generally show poorer agreement at low altitudes where $\mathrm{CH}_{2} \mathrm{O}$ mixing ratios are elevated and the box model input perturbations become increasingly more important. The median and average ratios for the lowest four altitudes below $4 \mathrm{~km}$ lie near or exceed the upper random uncertainty bound. Thus similar to Figure 5, on average the TDLAS measurements and box model results are in good agreement at and above $5 \mathrm{~km}$. The fact that there is no consistent measurement-model bias at these higher altitudes implies that there are no systematic errors in the model input, and therefore the rate constant uncertainties are probably much smaller than the stated systematic error bars, unless there are unknown temperature and pressure dependences in these rate constants. Nevertheless, Figure 6 shows a great deal of scatter in the measurement/model ratios, part of which arises from sampling in clouds as well as perturbations caused by convection.

[43] As discussed, MHP can be a very important $\mathrm{CH}_{2} \mathrm{O}$ precursor. During TRACE-P, Fried et al. [2003b] noted the importance of employing measured MHP mixing ratios in constraining the model calculations of $\mathrm{CH}_{2} \mathrm{O}$. Near the marine boundary layer the model sometimes overestimated 


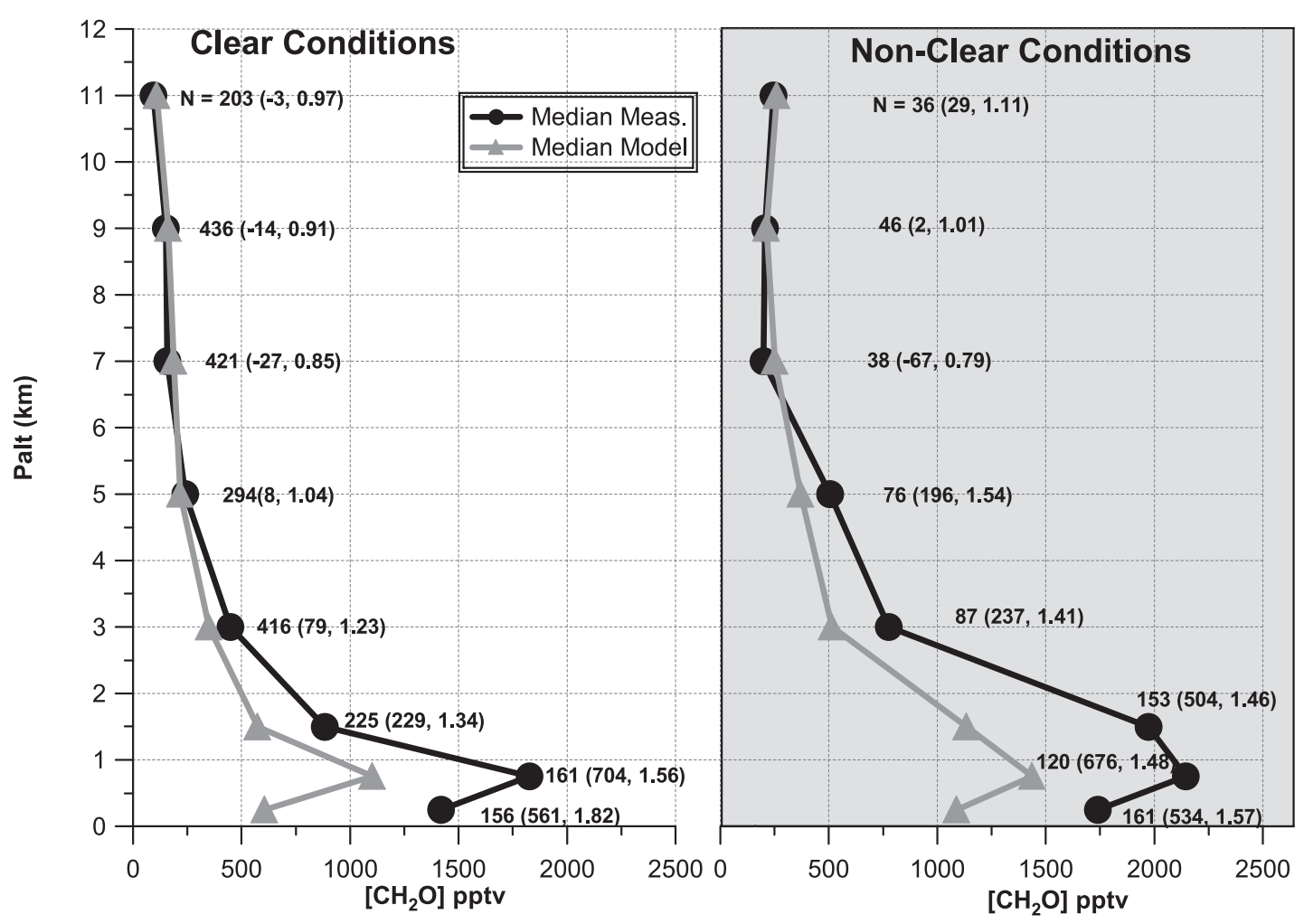

Figure 7. Pressure altitude bin medians for time coincident TDLAS (Meas.) and box model results for all locations. The comparisons are restricted to time periods where measurements of MHP are available for model input or when the MHP measurements are at the limit of detection. The number of comparison points is shown next to each point outside the parentheses, and the numbers in the parentheses are median point-by-point differences for (TDLAS - Box Model) and median TDLAS/Box Model ratios.

MHP mixing ratios, resulting in overestimated $\mathrm{CH}_{2} \mathrm{O}$ values in that study. In the present study, by contrast, the model underestimates MHP values in the UT during very fresh convection, resulting in underestimated $\mathrm{CH}_{2} \mathrm{O}$ values. It is important to note that missing measurements of MHP are not responsible for the boundary layer discrepancies shown in Figure 5 but contribute somewhat to the overall discrepancies shown in Figure 6, particularly in the UT. If we restrict our measurement-model comparisons to time periods when only MHP measurements are available for model input or when measured MHP values are at their limit of detection $(77 \%$ of the total measurement-model comparisons), the measurement/model ratios falling within the combined random uncertainty limits and systematic limits do not change from the values given above. However, this removes some of the large outliers in the UT in certain cases. For example, restricting comparisons to time periods where MHP measurements are available to constrain the model, changes the median point-by-point TDLAS/Box Model ratio from a value of 1.58 to 1.11 during nonclear time periods (to be discussed) in the $10-12-\mathrm{km}$ altitude bin.

\section{Comparisons in Clear Air Relative to Nonclear Conditions}

[44] As discussed in their analysis of TRACE-P data [Fried et al., 2003b], nonclear conditions associated with haze and clouds are often associated with fronts with the consequent transport of boundary layer pollution into the midtroposphere. Under such conditions, Fried et al. [2003b] showed that $\mathrm{CH}_{2} \mathrm{O}$ measurements and model results become elevated compared to cloud-free conditions, and depending upon the level of elevation, the observations could either be higher or lower than model values. During transport of significantly elevated $\mathrm{CH}_{2} \mathrm{O}$ and/or its precursors from the boundary layer, measurements by TDLAS during TRACE-P in clouds were consistently higher than model results, suggesting the presence of processes not represented in the model, such as direct convective transport. Formaldehyde trapped in the liquid phase may also be reemitted back into the gas phase as cloud particles evaporate, and this process is not represented in the box model. In less polluted transported air, by contrast, Fried et al. [2003b] also showed persistent model overestimations of $\mathrm{CH}_{2} \mathrm{O}$ and this was attributed to $\mathrm{CH}_{2} \mathrm{O}$ uptake in clouds not captured by the box model. All of these situations could occur at the same time, giving rise to good measurement-model agreement from the cancellation of various modeling errors. Nevertheless, for these reasons one can expect a high degree of variability in the relationship between measurements and box model results in clouds and this is shown by Figure 7.

[45] Figure 7 displays the time coincident TDLAS and box model medians for the eight altitude bins for all locations combined parsed by sampling conditions in clear versus nonclear conditions. The comparisons are restricted to time periods where measurements of MHP (including 
those at the LOD) are available for model input. Similar to TRACE-P results discussed by Fried et al. [2003b], clear and nonclear (haze, intermediate, and cloudy conditions) were determined from measurements of aerosol volume density for particles in 10-20 $\mu \mathrm{m}$ size range in conjunction with the DC-8 videotapes.

[46] As can be seen, differences between TDLAS and box model results are somewhat similar for the first two altitude bins ( 0 to $0.5 \mathrm{~km}$ and 0.5 to $1 \mathrm{~km}$ ) in both cases. This most likely reflects the model input perturbations previously discussed in the presence of fresh localized $\mathrm{CH}_{2} \mathrm{O}$ sources. Starting at $1 \mathrm{~km}$ and extending up to $6 \mathrm{~km}$, the differences between TDLAS and box model results become noticeably larger for nonclear compared to clear conditions and the absolute mixing ratios for both measurements and box model results are elevated in nonclear relative to clear conditions. The latter was also observed during TRACE-P [Fried et al., 2003b]. However, unlike TRACE-P, we do not observe obvious evidence of $\mathrm{CH}_{2} \mathrm{O}$ uptake since most of the sampling in clouds during INTEX occurred over continental North America (69\% of the cloud encounters occurred over the continent) where vertical convection of boundary layer pollution $\left(\mathrm{CH}_{2} \mathrm{O}\right.$ and its precursors $)$ most likely masks the presence of $\mathrm{CH}_{2} \mathrm{O}$ uptake. By contrast, nearly all of the cloud encounters during TRACE-P occurred over the Pacific Ocean.

[47] In the UT, Figure 7 shows that both the measurements and box model results are enhanced during nonclear conditions relative to clear conditions due to convection. In the 10$12 \mathrm{~km}$ altitude range this enhancement is over a factor of 2 . The box model in this case does a nice job of capturing the elevated observations. The companion paper by Fried et al. (submitted manuscript, 2008) will further discuss this topic.

\section{Summary}

[48] Two different instruments, a tunable diode laser absorption spectrometer (TDLAS) and a coil enzyme (CENZ) fluorometric method were operated on the NASA DC-8 aircraft during the summer INTEX-NA study to acquire $\mathrm{CH}_{2} \mathrm{O}$ measurements over North America and the North Atlantic Ocean from $\sim 0.2 \mathrm{~km}$ to $\sim 12.5 \mathrm{~km}$.

[49] The meteorological analysis by Fuelberg and colleagues determined that cold frontal passages over the East and Gulf coasts were more frequent than normal, and this brought record low temperatures to the south during the summer of 2004. These events resulted in lower isoprene emissions compared to other years and resulted in lower $\mathrm{CH}_{2} \mathrm{O}$ levels in the boundary layer and UT over this region during the summer of 2004. In spite of this, the median $\mathrm{CH}_{2} \mathrm{O}$ mixing ratio measured by TDLAS in the UT over continental North America is about a factor of 4 times higher than that observed in the UT over remote regions of the central and eastern Pacific Ocean during TRACE-P. These observations, together with the higher observed variability point to the influence of continental convection in perturbing UT $\mathrm{CH}_{2} \mathrm{O}$ levels over North America during summer months. Over the Atlantic Ocean, the median UT $\mathrm{CH}_{2} \mathrm{O}$ mixing ratio of 140 pptv is similar to continental values, indicating that transport of $\mathrm{CH}_{2} \mathrm{O}$ and its precursors and in situ production in the UT over more remote regions of the Atlantic Ocean is efficient. Many of the UT elevated
$\mathrm{CH}_{2} \mathrm{O}$ events occurred near the North American coastline, however, elevated $\mathrm{CH}_{2} \mathrm{O}$ observations as high as 400 pptv were also recorded long distances from the coastline.

[50] Measurements of $\mathrm{CH}_{2} \mathrm{O}$ by TDLAS were compared with box model results to further test our understanding of hydrocarbon oxidation chemistry under various conditions over continental North America and the North Atlantic Ocean. Averaged over the entire mission a bivariate regression plot indicated a measurement-model slope of 1.20. This, however, was altitude- and location-dependent; at altitudes below $0.5 \mathrm{~km}$ the median measurement/model ratio was 1.7 , with individual ratios significantly larger than this. This behavior, which was similar to TRACE-P, primarily reflects uncertainties in the box model inputs near source regions at low altitudes, the precise identifications for which need to be determined. The measurement/model ratios rapidly declined to median values in the 0.8 to 1.1 range in the $6-12-\mathrm{km}$ UT regime. A further comparison revealed that both measured and modeled $\mathrm{CH}_{2} \mathrm{O}$ were significantly elevated at all altitudes when sampling in nonclear conditions due to convection of pollution.

[51] Acknowledgments. The National Center for Atmospheric Research is operated by the University Corporation for Atmospheric Research under the sponsorship of the National Science Foundation. This research was supported by funds from the National Aeronautics and Space Administration's Global Tropospheric Experiment. The authors specifically wish to acknowledge the NASA DC-8 staff and crew for all their valuable support and assistance. The GEOS-CHEM model is managed by the Atmospheric Chemistry Modeling Group at Harvard University with support from the NASA Atmospheric Chemistry and Modeling Analysis Program.

\section{References}

Bertram, T. H., et al. (2007), Direct measurements of the convective recycling of the upper troposphere, Science, 315(5813), 816-820, doi:10.1126/science. 1134548 .

Carlier, P., H. Hannachi, and G. Mouvier (1986), The chemistry of carbonyl compounds in the atmosphere: A review, Atmos. Environ., 20, 20792099, doi:10.1016/0004-6981(86)90304-5.

Crawford, J. H., et al. (1999), Assessment of upper tropospheric $\mathrm{HO}_{\mathrm{x}}$ sources over the tropical Pacific based on NASA GTE/PEM data: Net effect on $\mathrm{HO}_{\mathrm{x}}$ and other photochemical parameters, J. Geophys. Res., 104(D13), 16,255-16,273, doi:10.1029/1999JD900106.

Dasgupta, P. K., J. Li, G. Zhang, W. T. Luke, W. A. McClenny, J. Stutz, and A. Fried (2005), Summertime ambient formaldehyde in five U.S. metropolitan areas: Nashville, Atlanta, Houston, Philadelphia, and Tampa, Environ. Sci. Technol., 39(13), 4767-4783, doi:10.1021/es048327d.

Fried, A., et al. (2003a), Tunable diode laser measurements of formaldehyde during the TOPSE 2000 study: Distributions, trends, and model comparisons, J. Geophys. Res., 108(D4), 8365, doi:10.1029/2002JD002208.

Fried, A., et al. (2003b), Airborne tunable diode laser measurements of formaldehyde during TRACE-P: Distributions and box-model comparisons, J. Geophys. Res., 108(D20), 8798, doi:10.1029/2003JD003451.

Frost, G. J., et al. (2002), Comparison of box model calculations and measurements of formaldehyde from the 1997 North Atlantic Regional Experiment, J. Geophys. Res., 107(D8), 4060, doi:10.1029/2001JD000896.

Fuelberg, H. E., M. J. Porter, C. M. Kiley, and D. Morse (2007), Meteorological conditions and anomalies during INTEX-NA, J. Geophys. Res., 112, D12S06, doi:10.1029/2006JD007734.

Guenther, A., T. Karl, P. Harley, C. Wiedinmyer, P. I. Palmer, and C. Geron (2006), Estimates of global terrestrial isoprene emissions using MEGAN (Model of Emissions of Gases and Aerosols from Nature), Atmos. Chem. Phys., 6, 3181-3210.

Harder, J. W., A. Fried, S. Sewell, and B. Henry (1997), Comparison of tunable diode laser and long path ultraviolet spectroscopic measurements of ambient formaldehyde concentrations during the $1993 \mathrm{OH}$ Photochemistry Experiment, J. Geophys. Res., 102, 6267-6282, doi:10.1029/ 96JD01731.

Heikes, B. G. (1992), Formaldehyde and hydroperoxides at Mauna Loa Observatory, J. Geophys. Res., 97(D16), 18,001-18,013.

Kormann, R., et al. (2003), Formaldehyde over the eastern Mediterranean during MINOS: Comparison of airborne in-situ measurements with 3D-model results, Atmos. Chem. Phys., 3, 851-861. 
Lazrus, A. L., K. L. Fong, and J. A. Lind (1988), Automated fluorometric determination of formaldehyde in air, Anal. Chem., 60, 1074-1078, doi:10.1021/ac00161a025.

Lee, M., B. G. Heikes, D. J. Jacob, G. Sachse, and B. Anderson (1997), Hydrogen peroxide, organic hydroperoxide, and formaldehyde as primary pollutants from biomass burning, J. Geophys. Res., 102(D1), 1301-1309, doi:10.1029/96JD01709.

Lee, M., B. G. Heikes, and D. J. Jacob (1998), Enhancements of hydroperoxides and formaldehyde in biomass burning impacted air and their effect on atmospheric oxidant cycles, J. Geophys. Res., 103(D11), 13,201-13,212, doi:10.1029/98JD00578.

Lee, Y.-N., et al. (1998), Atmospheric chemistry and distribution of formaldehyde and several multioxygenated carbonyl compounds during the 1995 Nashville/Middle Tennessee ozone study, J. Geophys. Res., 103(D17), 22,449-22,462, doi:10.1029/98JD01251.

Li, Q., D. J. Jacob, R. Park, Y. Wang, C. L. Heald, R. Hudman, R. M. Yantosca, R. V. Martin, and M. Evans (2005), North American pollution outflow and the trapping of convectively lifted pollution by upper-level anticyclone, J. Geophys. Res., 110, D10301, doi:10.1029/2004JD005039.

Li, Y. Q., K. L. Demerjian, M. S. Zahniser, D. D. Nelson, J. B. McManus, and S. C. Herndon (2004), Measurement of formaldehyde, nitrogen dioxide, and sulfur dioxide at Whiteface Mountain using a tunable diode laser system, J. Geophys. Res., 109, D16S08, doi:10.1029/2003JD004091.

Madronich, S. (1987), Photodissociation in the atmosphere 1. Actinic flux and the effect of ground reflections and clouds, J. Geophys. Res., 92, 9740-9752, doi:10.1029/JD092iD08p09740.

Millet, D. B., et al. (2006), Formaldehyde distribution over North America: Implications for satellite retrievals of formaldehyde columns and isoprene emission, J. Geophys. Res., 111, D24S02, doi:10.1029/2005JD006853.

Müller, J.-F., and G. Brasseur (1999), Sources of upper tropospheric $\mathrm{HO}_{\mathrm{x}}$ : A 3-dimensional study, J. Geophys. Res., 104(D1), 1705-1715, doi:10.1029/1998JD100005.

Nunnermacker, L. J., et al. (1998), Characterization of the Nashville urban plume on July 3 and July 18, 1995, J. Geophys. Res., 103(D21), 28,12928,148, doi:10.1029/98JD01961.

Olson, J. R., et al. (2001), Seasonal differences in the photochemistry of the South Pacific: A comparison of observations and model results from PEM-Tropics A and B, J. Geophys. Res., 106, 32,749-32,766, doi:10.1029/2001JD900077

Olson, J. R., J. H. Crawford, G. Chen, W. H. Brune, I. C. Faloona, D. Tan, H. Harder, and M. Martinez (2006), A reevaluation of $\mathrm{HO}_{\mathrm{x}}$ observations from NASA field campaigns, J. Geophys. Res., 111, D10301, doi:10.1029/2005JD006617.

O’Sullivan, D. W., B. G. Heikes, J. Snow, P. Burrow, M. Avery, D. R. Blake, G. W. Saschse, R. W. Talbot, D. C. Thornton, and A. R. Bandy (2004), Long-term and seasonal variations in the levels of hydrogen peroxide and methylhydroperoxide, and selected compounds over the Pacific Ocean, J. Geophys. Res., 109, D15S13, doi:10.1029/ 2003JD003689.

Palmer, P. I., D. J. Jacob, A. M. Fiore, R. V. Martin, K. Chance, and T. P. Kurosu (2003), Mapping of isoprene emissions over North America using formaldehyde column observations from space, J. Geophys. Res., 108(D6), 4180, doi:10.1029/2002JD002153.
Ren, X., et al. (2008), $\mathrm{HO}_{\mathrm{x}}$ chemistry during INTEX-A 2004: Observation, model calculation, and comparison with previous studies, J. Geophys. Res., 113, D05310, doi:10.1029/2007JD009166.

Roller, C., A. Fried, J. Walega, P. Weibring, and F. Tittel (2006), Advances in hardware, system diagnostics software, and acquisition procedures for high performance airborne tunable diode laser measurements of formaldehyde, Appl. Phys. B, 82(2), 247-264, doi:10.1007/s00340-005-1998-8.

Sander, S. P., et al. (2006), Chemical kinetics and photochemical data for use in atmospheric studies evaluation number 15, JPL Publ., 06-2, 522

pp..
Singh, H. B., W. H. Brune, J. H. Crawford, D. J. Jacob, and P. B. Russell (2006), Overview of the summer 2004 Intercontinental Chemical Transport Experiment-North America (INTEX-A), J. Geophys. Res., 111, D24S01, doi:10.1029/2006JD007905.

Snow, J., B. G. Heikes, H. Shen, D. O’Sullivan, A. Fried, and J. Walega (2007), Hydrogen peroxide, methyl hydroperoxide, and formaldehyde over North America and the North Atlantic, J. Geophys. Res., 112, D12S07, doi:10.1029/2006JD007746.

Thomas, E. R., G. J. Frost, and Y. Rudich (2001), Reactive uptake of ozone by proxies for organic aerosols: Surface-bound gas-phase products, J. Geophys. Res., 106(D3), 3045-3056, doi:10.1029/2000JD900595.

Wert, B. P., et al. (2003a), Signatures of terminal alkene oxidation in airborne formaldehyde measurements during TexAQS 2000, J. Geophys. Res., 108(D3), 4104, doi:10.1029/2002JD002502.

Wert, B. P., A. Fried, S. Rauenbuehler, J. Walega, and B. Henry (2003b), Design and performance of a tunable diode laser absorption spectrometer for airborne formaldehyde measurements, J. Geophys. Res., 108(D12), 4350, doi:10.1029/2002JD002872.

G. Chen, J. H. Crawford, and J. Olson, NASA Langley Research Center, Mail Stop 401B, Hampton, VA 23681, USA.

A. Fried, D. Richter, J. G. Walega, and P. Weibring, Earth Observing Laboratory, National Center for Atmospheric Research, 3450 Mitchell Lane, Boulder, CO 80301, USA.

H. Fuelberg, J. Halland, and M. Porter, Department of Meteorology, Florida State University, Tallahassee, FL 32306-4520, USA.

B. G. Heikes and H. Shen, Center for Atmospheric Chemistry Studies, Graduate School of Oceanography, University of Rhode Island, Narragansett, RI 02882-1197, USA.

D. B. Millet, Department of Soil, Water, and Climate, University of Minnesota, Borlaug Hall, 1991 Upper Buford Circle, St. Paul, MN 55108, USA.

D. W. O'Sullivan, Department of Chemistry, United States Naval Academy, Annapolis, MD 21402-5000, USA.

C. Roller, Ekips Technology Incorporated, 710 Asp Avenue, Suite 500, Norman, OK 73069, USA.

J. Snow, Department of Geography, Geology, and the Environment, Slippery Rock University, Slippery Rock, PA 16057, USA.

F. Tittel, Electrical and Computer Engineering Department, Rice University, Mail Stop 366, 6100 Main Street, Houston, TX 77005-1892, USA. 